\title{
17. GRAIN FABRIC MEASURED USING MAGNETIC SUSCEPTIBILITY ANISOTROPY IN DEFORMED SEDIMENTS OF THE BARBADOS ACCRETIONARY PRISM: LEG 110 ${ }^{1}$
}

\author{
M. W. Hounslow 2,3
}

\begin{abstract}
The anisotropy of magnetic susceptibility documents the generation of tectonically produced fabrics in sediments that macroscopically show no evidence of this disruption. The fabric observed in initial accretion is largely produced by overprinting of the original sedimentary susceptibility anisotropy by an E-W horizontal tectonic shortening and vertical extension. The response of the sediments to stress during initial accretion is variable, particularly near the sediment surface, and appears to reflect the inhomogeneous distribution of strain rate in the overthrust sequence. The susceptibility anisotropy of sediments possessing scaly fabric is consistent with the strong orientation of phyllosilicates seen in thin section, producing a $\mathrm{K}_{\min }$ normal to the scalyness. The slope sediments deposited on the accreted sequence are also affected by tectonic shortening. The accreted sequences at Sites 673 and 674 show a complex history of fabric modification, with previous tectonic fabrics overprinted by later fabric modifications, pointing to continued tectonic shortening during the accretion process. The form of the susceptibility anisotropy axes at Sites 673 and 674 is consistent with NESW shortening, probably reflected in the NW-SE surface expression of the out-of-sequence thrusts. The susceptibility anisotropy appears to document a downhole change in the trend of shortening from $\mathrm{E}$ to $\mathrm{W}$ at the surface to more NESW at depth, probably as a result of the obliquely trending basement ridge, the Tiburon Rise.
\end{abstract}

\section{INTRODUCTION}

To a large extent the grain fabric of a rock is indicative of the stresses that were imposed upon it during its formation, and therefore the fabric can be used as a delimiter in defining these stresses. The deformed sediments in present day accretionary prisms provide the natural laboratory for studying the mechanisms of grain fabric modification, because the present and past conditions in them can be reasonably well defined. Such studies have important implications for understanding the grain fabric in ancient low-temperature metamorphic rocks.

The sediments recovered on ODP Leg 110, through the toe of the northern Barbados Ridge accretionary prism, potentially reflect both the fabric generated in normal deep-sea sediments and the stresses imposed by incorporation in the prism. The fabric of the sediments at the toe of the prism, will be examined using anisotropy of magnetic susceptibility (AMS), a technique that has been widely used in examining the fabric of sediments and tectonic rocks under a wide variety of conditions (Hrouda, 1982). This study examines the development of grain fabric in the deformed overthrust sediments, with a view to determining the strain and stress history imposed during the structural modifications accompanying accretion.

\section{STRUCTURAL FEATURES}

The Barbados Ridge forms the leading edge of the Caribbean Plate, under which the Atlantic Plate has been subducting at least since the Eocene, the process of which has lead to the formation of the Lesser Antilles Island Arc (Fig. 1). The forearc region consists of both forearc basins, such as the Tobago Trough, and material scraped off the incoming Atlantic Plate (Mascle et al., 1986; Brown and Westbrook, 1987). The only subaerially exposed part of the accretionary prism is that out-

\footnotetext{
${ }^{1}$ Moore, J. C., Mascle, A., et al., 1990. Proc. ODP, Sci. Results, 110: College Station, TX (Ocean Drilling Program).

2 Department of Geology, University of Sheffield, Sheffield S3 7HF, United Kingdom.

${ }^{3}$ Current address: School of Environmental Sciences, University of East Anglia, Norwich NR4 7TJ, United Kingdom.
}

cropping on Barbados (Speed, 1983). The deformation front forms the eastern boundary of the prism, and is marked by the first occurrence of large-scale deformation. The sediments from the accretionary prism at the drill site latitude show a surface structural grain that is oriented approximately $\mathrm{N}$ to $\mathrm{S}$ (Fontas et al. 1984; Mauffret et al., 1984), presumably reflecting the local collision direction of the Tiburon Rise and the toe of the accretionary prism.

The structural features at the toe of the prism (Sites 541, 542, 671,675 , 676, Fig. 1) document relatively simple folding and thrusting of the Pleistocene-to-Miocene sedimentary sequence above the décollement horizon, located in lower Miocene mudstones (Behrmann et al., 1988; Mascle, Moore, et al., 1988). The décollement horizon is characterized by a penetrative subhorizontal fracture termed scaly fabric, which is well documented from other forearc regions and is attributed to tectonic deformation (Moore et al., 1985). Sub-horizontal scaly fabric is also developed in several horizons above the level of the décollement. The underthrust sequence is for the most part structurally unaffected by the plate collision.

Several kilometers arcward of the frontal thrust the sequence at Sites 673 and 674 document more extensively tectonized sediments with overturned limbs, tight folding, stratal disruption, calcite veining, subvertical to horizontal dipping scaly fabrics, and stratigraphically complicated by further thrusting. A slope sequence of apparently normally deposited hemipelagic sediments and slump deposits is also found above the accreted sequence. This has resulted in a stratigraphic and structural pattern that is much more complicated than that found at Site 671 .

\section{ANISOTROPY OF MAGNETIC SUSCEPTIBILITY}

In titanomagnetite-bearing sediments, the anisotropy of magnetic susceptibility (AMS) has been shown to represent a measure of the grain shape orientation of the detrital quartz grains (Rees, 1965), and has been widely used in examining deep-sea sediments (Ellwood and Ledbetter, 1977; Hailwood et al., 1987). In moderately deformed tectonic rocks it has been suggested that the AMS is quantitatively related to the magnitude of the strain ellipsoid, with some authors suggesting a universal relationship (Kligfield et al., 1977; Henry and Daly, 1983). 


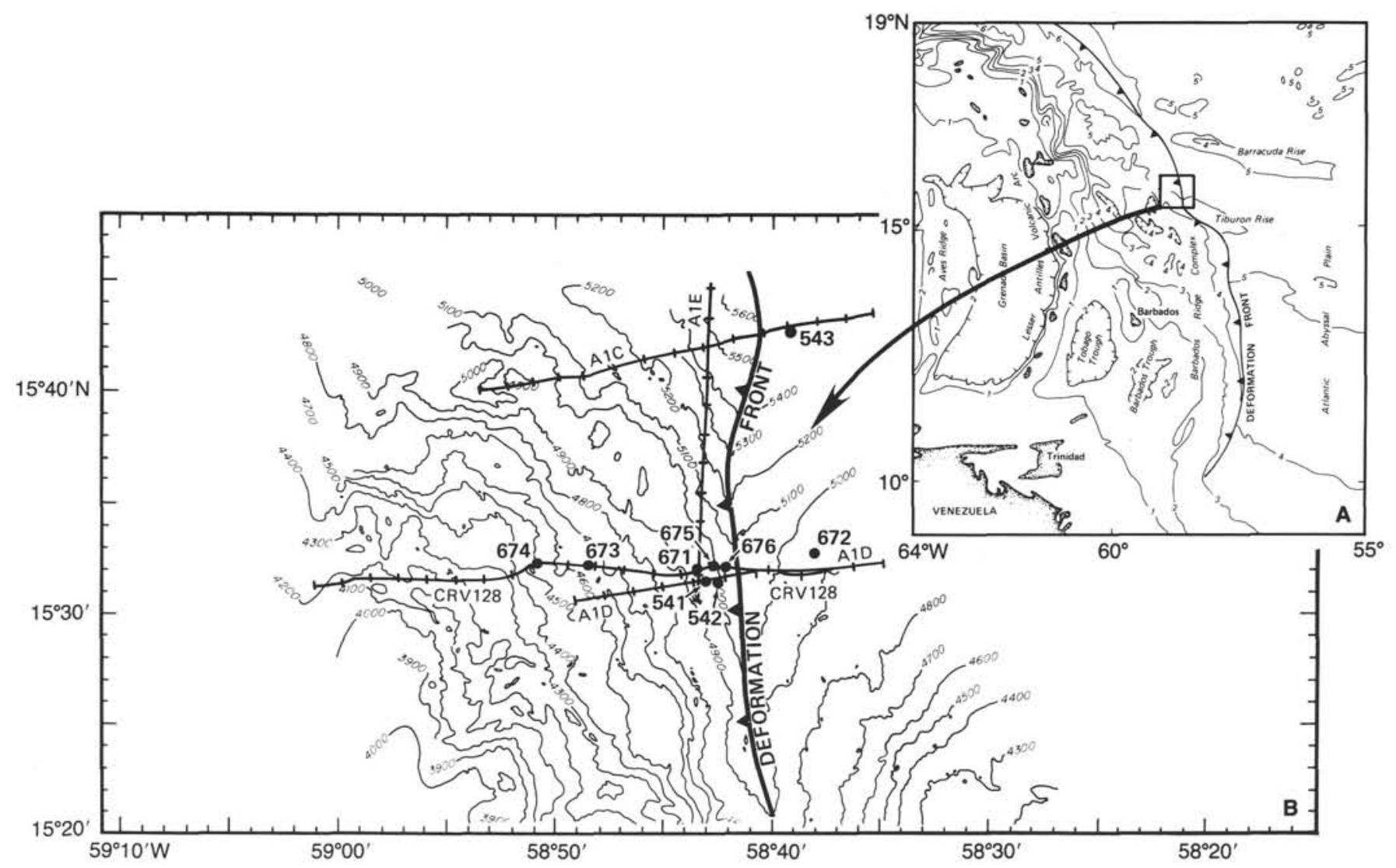

Figure 1. Location of ODP and DSDP sites relative to topographic features, seismic lines, and bathymetry. Contour interval, $100 \mathrm{~m}$.

The AMS is defined by the direction and magnitude of three orthogonal axes, $K_{\max }, K_{\mathrm{int}}$, and $K_{\min }$. The $K_{\min }$ axis is normal to the foliation plane, which is approximately parallel to the bedding in undeformed sediments and contains both the $K_{\max }$ and $K_{\text {int }}$ axes. The preferred grain long axis orientation within the foliation plane is parallel to the $K_{\max }$ axis.

There are a wide variety of parameters that have been used to describe the axial magnitude relationships of the susceptibility ellipsoid. Two parameters that have been widely used in other studies of deep-sea sediments are the $h \%$ and $q$ values (Hamilton and Rees, 1970), where:

$$
\begin{gathered}
h \%=\left[\left(K_{\max }-K_{\min }\right) \times 100\right] / K_{\text {int }} \\
\left.q=\left[K_{\max }-K_{\text {int }}\right] /\left[\left(\left(K_{\max }+K_{\text {int }}\right) / 2\right)-K_{\min }\right)\right] .
\end{gathered}
$$

To aid comparison with terrestrial tectonic rocks, in which workers use a different set of parameters, $P_{1}\left(K_{\max } / K_{\text {int }}\right)$ and $P_{3}$ $\left(K_{\text {int }} / K_{\min }\right)$ have also been determined. These two parameters are widely used because of their similarity to the strain ellipsoid axial ratios (Kligfield et al., 1977).

\section{SAMPLING AND MEASUREMENT TECHNIQUES}

The AMS of samples from Sites 671, 673, and 674 have been determined after the remanent magnetization measurements described by Hounslow et al. (this volume). The AMS was determined using a MOLSPIN susceptibility anisotropy meter which to a certain extent is sensitive to the sample shape, so that samples with a susceptibility below $57 \times 10^{-5}$ SI could not be reliably measured (Hounslow et al., 1988). The susceptibility of each sample, which is needed for the complete AMS specification, was measured using a MOLSPIN susceptibility unit.

The AMS has been oriented into geographic coordinates by assuming that the high-coercivity remanent magnetization component recovered from each sample is the north direction for positive inclinations and south for negative inclinations (Hounslow et al., this volume).

\section{Accuracy of the Orienting Procedure}

The directional consistency of the AMS in a single APC core, with reference to the core liner fiducial, provides a measure of the actual in-situ scatter of the AMS directions (assuming there is no significant twist during corer penetration). The sub-sample oriented AMS indicates both the in-situ scatter and the scatter introduced by assuming that the individual sample remanent magnetization direction represents the geomagnetic field orientation. The AMS axes are generally better clustered when plotted relative to the core liner fiducial than when using the sub-sample data, as might be expected (Table 1, Fig. 8, and Appendix). When data from several cores are plotted using the mean core orientation and compared to that using the sub-sample data, the overall distribution of axes is very similar. The average difference for all holes, in the mean $K_{\max }$ values, between the sub-sample and the whole core oriented is $15^{\circ}$, with $9^{\circ}$ for Hole $671 \mathrm{~B}$ and $22^{\circ}$ for Holes 673A, 673B, and 674A combined. This indicates that, at least for the APC cores, sub-sample orientation yields generally correct mean directions, if not necessarily the degree of in-situ scatter.

The coincidence of the core mean geomagnetic field direction and the north direction derived from the Eastman-Whip- 
Table 1. Summary of AMS data for APC cores from Holes 671B, 673A, 673B, and 674A. The von Mises circular standard deviation is quoted for the declination, and the arithmetic standard deviation for the inclination. Core means for whole-core rotation (using average remanence declination) and sub-sample rotation are indicated; $\mathbf{n}$ is the number of samples.

\begin{tabular}{|c|c|c|c|c|c|c|c|c|c|c|c|c|c|c|c|c|c|}
\hline \multirow{3}{*}{$\begin{array}{l}\text { Hole/ } \\
\text { Core }\end{array}$} & \multicolumn{8}{|c|}{ Whole core rotation } & \multicolumn{4}{|c|}{ Sub-sample rotation } & \multirow[b]{3}{*}{$P_{1}$} & \multirow[b]{3}{*}{$P_{3}$} & \multirow[b]{3}{*}{$q$} & \multirow[b]{3}{*}{$h \%$} & \multirow[b]{3}{*}{$\mathrm{n}$} \\
\hline & \multicolumn{4}{|c|}{$K_{\max }$} & \multicolumn{4}{|c|}{$K_{\min }$} & \multicolumn{2}{|c|}{$K_{\max }$} & \multicolumn{2}{|c|}{$K_{\min }$} & & & & & \\
\hline & Dec & $\pm \mathrm{CSD}$ & Inc & $\pm \mathrm{SD}$ & Dec & $\pm \mathrm{CSD}$ & Inc & $\pm \mathrm{SD}$ & Dec & $\pm \mathrm{CSD}$ & Dec & $\pm \mathrm{SD}$ & & & & & \\
\hline \multicolumn{18}{|l|}{ 671B- } \\
\hline $1 \mathrm{H}$ & 039 & 39 & -60 & 27 & 126 & 15 & -19 & 24 & 211 & 56 & 139 & 21 & 1.0041 & 1.0048 & 0.70 & 0.9 & 6 \\
\hline $2 \mathrm{H}$ & 151 & 42 & -36 & 27 & 050 & 15 & -23 & 40 & 133 & 37 & 052 & 25 & 1.0045 & 1.0043 & 0.97 & 0.9 & 6 \\
\hline $3 \mathrm{H}$ & 333 & 18 & -19 & 24 & 052 & 28 & -47 & 29 & 153 & 15 & 234 & 28 & 1.0107 & 1.0060 & 0.98 & 1.7 & 6 \\
\hline $4 \mathrm{H}$ & 000 & 29 & -40 & 37 & 085 & 37 & -38 & 36 & 002 & 28 & 083 & 39 & 1.0102 & 1.0073 & 0.80 & 1.7 & 6 \\
\hline $5 \mathrm{H}$ & 208 & 14 & -13 & 6 & 108 & 22 & -32 & 28 & 360 & 18 & 260 & 21 & 1.0070 & 1.0079 & 0.67 & 1.5 & 7 \\
\hline $6 \mathrm{H}$ & 335 & 16 & -28 & 29 & 051 & 32 & -43 & 32 & 159 & 18 & 239 & 34 & 1.0085 & 1.0075 & 0.81 & 1.6 & 6 \\
\hline $7 \mathrm{H}$ & 359 & 16 & -5 & 3 & 090 & 38 & -74 & 5 & 194 & 32 & 120 & 50 & 1.0098 & 1.0190 & 0.46 & 2.8 & 7 \\
\hline $8 \mathrm{H}$ & 358 & 19 & -15 & 14 & 259 & 32 & -33 & 30 & 179 & 12 & 084 & 30 & 1.0143 & 1.0092 & 0.95 & 2.4 & 6 \\
\hline $9 \mathrm{H}$ & 009 & 16 & -12 & 12 & 102 & 30 & -56 & 26 & 007 & 21 & 120 & 28 & 1.0111 & 1.0118 & 0.77 & 2.3 & 6 \\
\hline $10 \mathrm{H}$ & 150 & 35 & -7 & 3 & 217 & 61 & -55 & 30 & 316 & 40 & 144 & 56 & 1.0131 & 1.0126 & 0.69 & 2.0 & 4 \\
\hline \multicolumn{18}{|l|}{$673 \mathrm{~A}-$} \\
\hline $1 \mathrm{H}$ & 047 & 26 & -16 & 3 & 305 & 40 & -28 & 20 & 224 & 46 & 033 & 70 & 1.0038 & 1.0047 & 0.64 & 0.8 & 2 \\
\hline $2 \mathrm{H}$ & 087 & 49 & -20 & 13 & 131 & 40 & -59 & 6 & 024 & 45 & 014 & 53 & 1.0070 & 1.0161 & 0.38 & 2.3 & 5 \\
\hline $3 \mathrm{H}$ & 027 & 39 & -24 & 8 & 036 & 22 & -54 & 9 & 013 & 8 & 350 & 40 & 1.0081 & 1.0166 & 0.42 & 2.4 & 3 \\
\hline \multicolumn{18}{|l|}{ 673B- } \\
\hline $2 \mathrm{H}$ & 019 & 38 & -27 & 30 & 353 & 40 & -40 & 18 & 169 & 46 & 340 & 40 & 1.0071 & 1.0129 & 0.54 & 2.0 & 3 \\
\hline $3 \mathrm{H}$ & 140 & 1 & -15 & 8 & 217 & 5 & -38 & 4 & 168 & 16 & 244 & 22 & 1.0044 & 1.0125 & 0.30 & 1.7 & 2 \\
\hline $4 \mathrm{H}$ & 129 & 41 & -44 & 20 & 058 & 18 & -18 & 10 & 321 & 43 & 242 & 39 & 1.0049 & 1.0105 & 0.39 & 1.5 & 3 \\
\hline $5 \mathrm{H}$ & 159 & 51 & -31 & 16 & 287 & 15 & -45 & 23 & 012 & 30 & 120 & 28 & 1.0123 & 1.0185 & 0.41 & 3.0 & 4 \\
\hline $6 \mathrm{H}$ & 002 & 26 & -15 & 8 & 071 & 41 & -46 & 19 & 165 & 36 & 215 & 39 & 1.0071 & 1.0189 & 0.30 & 2.6 & 7 \\
\hline \multicolumn{18}{|l|}{$674 \mathrm{~A}}$. \\
\hline $1 \mathrm{H}$ & 023 & 28 & -29 & 24 & 146 & 43 & -46 & 23 & 021 & 30 & 145 & 42 & 1.0029 & 1.0042 & 0.69 & 0.7 & 5 \\
\hline $3 \mathrm{H}$ & 284 & 34 & -39 & 19 & 158 & 53 & -29 & 9 & 088 & 43 & 154 & 54 & 1.0089 & 1.0093 & 0.72 & 1.8 & 4 \\
\hline
\end{tabular}

stock multishot orientation device is generally poor (Hounslow et al., this volume), although using either method of whole-core orientation does not show a significant difference in the overall direction of the AMS axes (Fig. 8 and Appendix). For the samples from XCB cores in Hole 671B (below $91 \mathrm{mbsf}$ ), the consistency of the direction of the AMS axes is good evidence that the sub-sample orienting procedure is generally applicable and does not introduce excessive scatter. This would also seem to be generally true for data at Sites 673 and 674 .

\section{Statistics}

The mean AMS $K_{\min }, K_{\max }$ declination, and inclination have been determined using von Mises two-dimensional angular statistics for the declination (Mardia, 1972) and arithmetic mean statistics for the inclination. Fisher statistics have not been used because of the strongly bimodal nature of many of the principal axis distributions, and hence would be inappropriate for this analysis. This combination of statistical techniques is not ideal, but is simple without resorting to more complicated statistics. The variance parameters, circular standard deviation (CSD, in degrees), and standard deviation (SD, in degrees) are quoted for the declination and inclination, respectively. Other average AMS parameters quoted are the arithmetic means.

\section{SOURCE OF THE SUSCEPTIBILITY ANISOTROPY}

It is important to identify the mineral source of the susceptibility anisotropy because this determines the form of the resulting AMS and its evolution with stress (Hrouda, 1982). An AMS derived from titanomagnetites will indicate the preferred grain shape orientation, whereas that from other minerals will be related to their preferred crystallographic orientation. The remanent magnetization behavior of these samples indicates that the dominant ferromagnetic mineral is titanomagnetite (Hounslow et al., this volume). In sediments from the Pleistocene, Pliocene, and Miocene the titanomagnetite is dominantly derived from volcanic ash (Hounslow, this volume), although this does not necessarily mean that the AMS is also derived from this ferromagnetic mineral.

To investigate what minerals give rise to the AMS, the relative amplitude of the magnetic anisotropy (the relative peak magnetic torque) was determined for a variety of magnetic fields on a high field torque magnetometer (Collinson, 1983). The variation of this property with magnetic field is indicative of the type of minerals giving rise to the anisotropy (Owens and Bamford, 1976). The magnetic torque measurements were performed on representative samples from a variety of sediment types with a range of susceptibilities. An AMS that results from titanomagnetite shows a plateau in the torque values by about 0.3 T (e.g., Sample 110-671B-30X-2, 63-65 cm; Fig. 2). An anisotropy that results from paramagnetic or diamagnetic minerals has a linear relationship with the square of the applied field (e.g., Sample 110-671B-67X-4, 75-77 cm; Fig. 2). Combinations of titanomagnetites and paramagnetic minerals show a saturation knee at about $0.3 \mathrm{~T}$, with a linearly increasing relationship at higher fields (e.g., Sample 110-671B-36X-2, 15-17 $\mathrm{cm}$; Fig. 2). The samples investigated show a range of relationships, with some possessing more complex behavior because of multispectral components in the torque curves probably produced by a preferred crystallographic orientation of the titanomagnetites (Stacey, 1960).

A parameter $T_{\mathrm{p}} / T_{0.1}$ describing the torque curves was calculated to estimate the relative proportion of the ferromagnetic saturation component and the paramagnetic/diamagnetic linear component in the samples. The upper, linear part of the $\mathrm{H}^{2}$ torque relationship was projected to intersect with the peak torque axis at $H=0$, the intersection value called $T_{\mathrm{p}}$. The $T_{\mathrm{p}} /$ $T_{0.1}$ parameter describes the ratio of $T p$ to the torque at $0.1 T^{2}$. This value is near zero for anisotropies dominated by paramagnetic/diamagnetic minerals and near 1.0 for anisotropies dominated by titanomagnetite. The relationship of this parameter with the sample susceptibility shows clearly that samples with susceptibilities above $90 \times 10^{-5}$ SI are dominated by anisotropy 


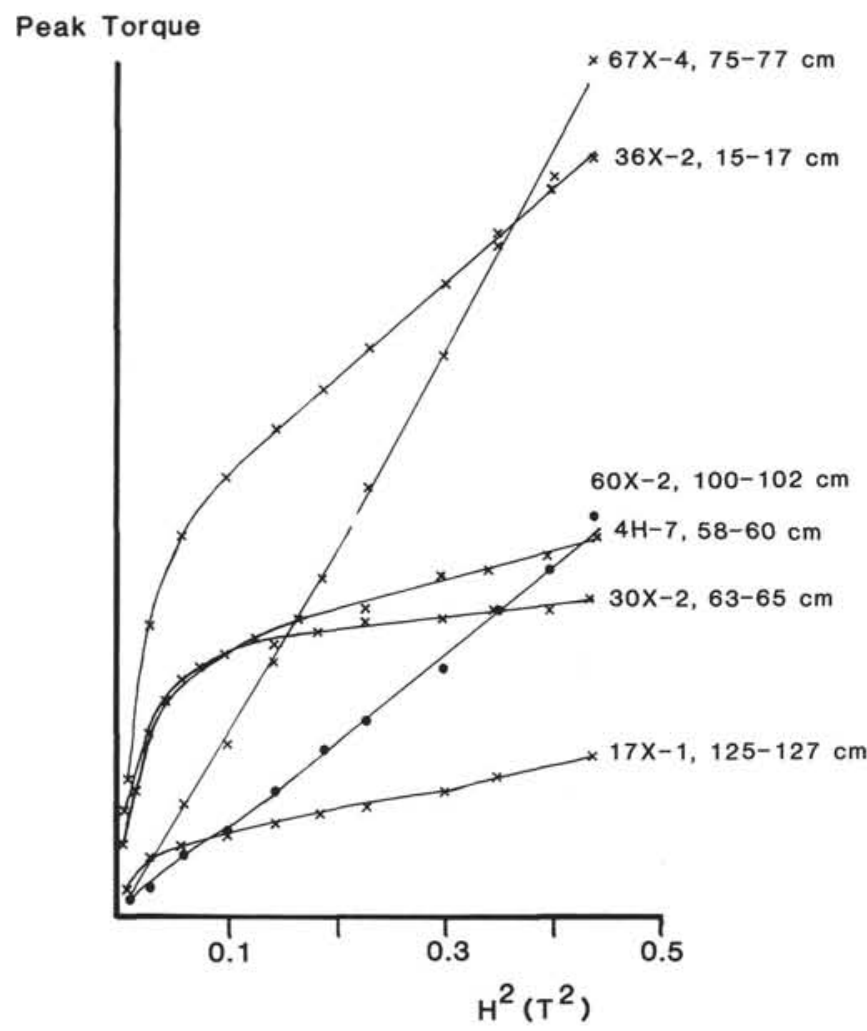

Figure 2. Magnetic torque vs. the square of the applied field for a variety of sediment types from Hole 671B. Crosses-calcareous mudstone and marl; filled circles-claystone and mudstone.

from titanomagnetite, some of which have significant paramagnetic/diamagnetic components, while those with susceptibilities below this value are dominated by paramagnetic/diamagnetic minerals (Fig. 3). The value of $90 \times 10^{-5} \mathrm{SI}$ is assumed to be a cut-off value in defining which samples have an AMS from ferromagnetic minerals, hence identifying possible mineral-related influences. Which paramagnetic minerals give rise to this AMS are unknown but likely candidates are Fe-rich minerals such as amphiboles, pyroxenes, chlorite and other micas (Hounslow, 1985).

\section{AMS OF SEDIMENTS FROM SITES 671, 673, AND 674}

As a result of the different structural histories of sediments cored at Sites 671 compared to 673 and 674, the detailed interpretation is divided into units that correspond approximately to the structural packets. The AMS of samples from Hole 671 appears to be at a much earlier stage in the deformation process than that at Sites 674 and 673, and therefore has much to tell us about the likely origins of the fabrics at these later sites, and is dealt with first. The slope sequences encountered at Sites 673 and 674 also have a different structural history compared to the underlying accreted sequence.

\section{FABRIC OF SEDIMENTS IN INITIAL ACCRETION-SITE 671}

The overthrust sedimentary sequence in $671 \mathrm{~B}$ shows relatively simple structural features, with no macroscopic evidence of large-scale fabric disruption or modification (Moore et al., 1988). A major thrust at $128 \mathrm{~m}$ places shallowly dipping Pleistocene to upper Miocene marls over lower Pleistocene to lower Miocene marls with moderate to shallow bedding dips. The

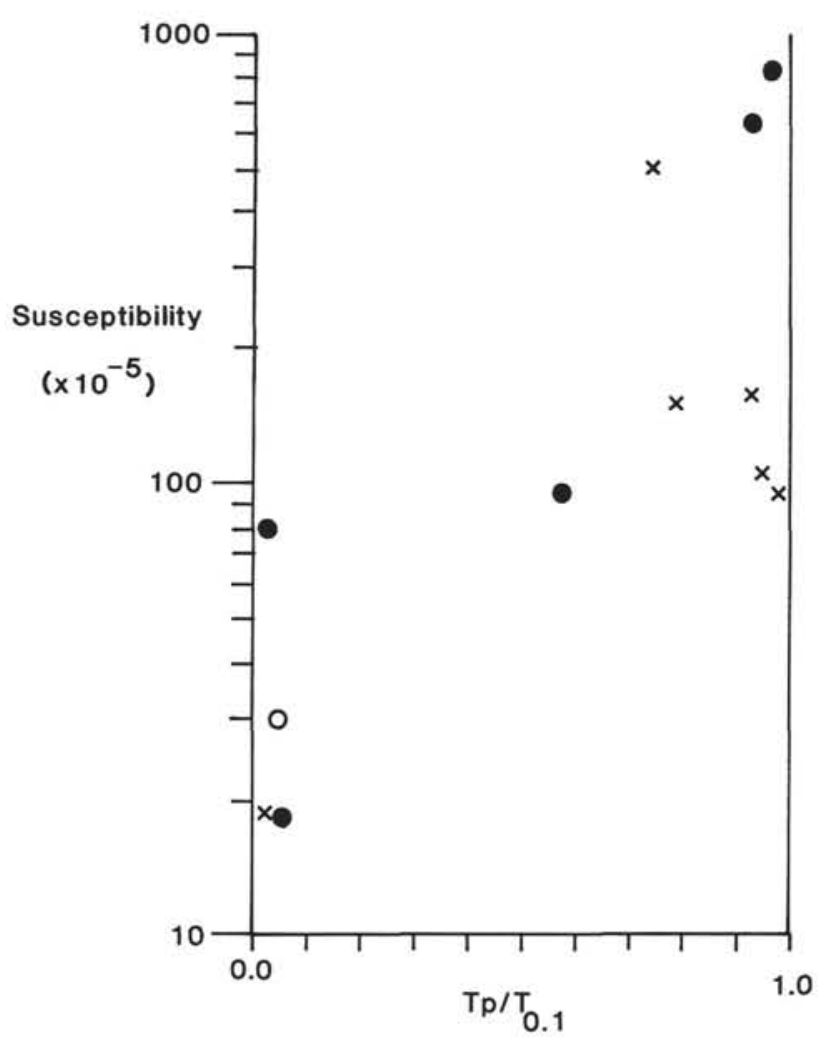

Figure 3. The volume magnetic susceptibility in SI units vs. $T_{\mathrm{p}} / T_{0.1}$ for samples from Holes 671B and 674A. See text for details. Crosses-calcareous mudstone and marl; filled circles-claystone and mudstone; open circles-radiolarian mudstone.

décollement horizon (500-540 m, developed in lower Miocene radiolarian-rich mudstones) has well-developed scaly fabric (Brown, this volume).

In the sequence above $128 \mathrm{~m}$ the $K_{\min }$ directions are smeared out in a girdle trending $86^{\circ}$ (Figs. 4 and 5A), and the $K_{\max }$ axes have low inclinations in a N-S trend (Fig. 4 and Table 2). Samples from Cores 110-671B-27X to -40X show little or no girdling (Fig. 5C) of the $K_{\min }$ axes, whereas the samples between Cores $110-671 \mathrm{~B}-17 \mathrm{X}$ to $-25 \mathrm{X}$ show an intermediate amount of girdling of the $K_{\min }$ axes. From 0 to 200 mbsf a high proportion of the samples have come from cores with sub-horizontal bedding dips (Mascle, Moore, et al., 1988), which indicates the AMS is incompatible with the fabric being formed from normal depositional processes (Hamilton and Rees, 1970; Hrouda, 1982; Hailwood et al., 1987). The type of AMS observed is similar to that developed in progressively strained tectonic rocks (Owens, 1974; Hrouda and Janak, 1976; Kligfield et al., 1981; Hrouda, 1982).

\section{AMS OF SEDIMENTS UNDERGOING PROGRESSIVE STRAIN}

The effect of progressive plane strain on an original sedimentary fabric has been numerically modeled by Owens (1974) and shown to go through a number of stages that closely match those seen in tectonic rocks (Graham, 1966; Kligfield et al., 1981; Hrouda, 1982). Initial shortening parallel to the bedding plane changes the oblate sedimentary AMS (stage 1) to a more triaxial or prolate AMS (stage 2), with $K_{\max }$ oriented parallel to the bedding/cleavage plane intersection, and subsequently to an oblate AMS with $K_{\min }$ normal to the cleavage (stage 3 ). More intense shortening produces a prolate or triaxial AMS with $K_{\max }$ parallel to the maximum extension direction (Fig. 6). This is 

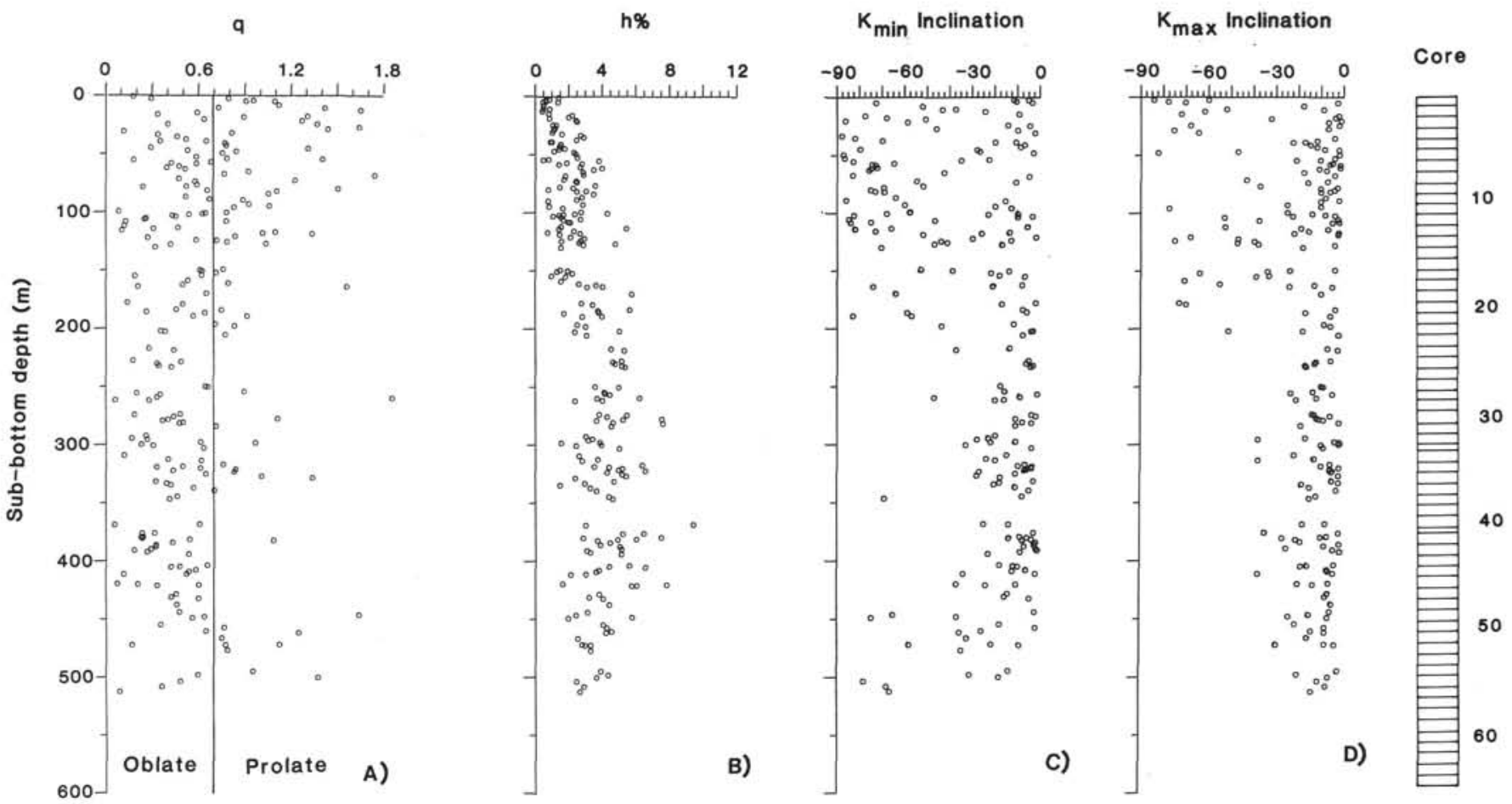

Figure 4. AMS axial magnitude parameters, A) $q$, B) $h \%$, C) $K_{\min }$ and D) $K_{\max }$ axis inclinations for all samples from Hole $671 \mathrm{~B}$, plotted relative to the sub-bottom depth. Correspondences to the core numbers are also shown.

achieved because during progressive strain the grain long axes tend to rotate toward the maximum extension direction. The AMS developed for a particular strain state depends upon the initial sedimentary AMS, the rate at which evolution of the grain shape distribution is achieved, and the stress history (Owens, 1974). For example, tectonic shortening perpendicular to the bedding plane will develop stage 3 and 4 only, as the original oblate sedimentary fabric will be close in orientation to that tectonic fabric developed parallel to the cleavage plane (Fig. 6). Progressive folding will lead to more complex behavior because the original sedimentary fabric will be at various orientations around the fold relative to the shortening direction (Hrouda, 1982).

\section{INTERPRETATION}

Overall the AMS observed at Hole 671B is similar to that found in tectonites with a slaty cleavage (stage 2 to 3 ; Kligfield et al., 1981; Borradaile and Tarling, 1981), even though there is no evidence of such a textural development. The AMS of samples between 0 and 128 mbsf is formed by tectonic modification of the original horizontal oblate sedimentary fabric, with a consequent smearing of the $K_{\max }$ axes. The AMS observed below about 200 mbsf (Fig. 5C, 6D) appears to have a more intensely developed tectonic overprint, with both $K_{\min }$ and $K_{\max }$ with dominantly shallow dips. The AMS ellipsoid shape also changes from a triaxial/prolate shape in Cores 110-671B-1H to -11X (excluding Core $110-671 \mathrm{~B}-7 \mathrm{H})$ to an oblate shape in Cores 110671B-20X to -30X (Fig. 7 and Table 2) again suggesting a downward increase in strain. However, this change could be due to the steeper bedding dips below $200 \mathrm{mbsf}$, so leading to complimentary tectonic and original sedimentary fabrics. The AMS features imply that the maximum tectonic extension direction is vertical and the shortening direction is sub-horizontal and approximately $250^{\circ}$, in general agreement with modeling studies (Ngokwey, 1984). The trend of the $K_{\max }$ axes (Table 2) slightly to the west of north coincides with the surface structural grain ob- served on side-scan sonargraphs at the prism toe (Belderson et al., 1984), pointing to fold axes aligned approximately $160^{\circ}-$ $340^{\circ}$. The mean $K_{\max }$ direction for the top 10 cores being slightly more N-S, than those below Core 110-671B-27X may indicate a $20^{\circ}$ shift in the shortening direction between these sediment packets (Table 2).

An important feature of the AMS at Site 671 is the progressive downward increase, at least to about $350 \mathrm{~m}$, in the degree of anisotropy, $h \%$ (Fig. 4B). I suggest this increase is primarily a function of compaction, which may be aided by a downward increase in the degree of tectonic shortening. Compaction alone produces a decrease in the amount of interpore water and a probable progressive increase in grain rotation into the horizontal plane. Such compaction-induced grain rotation has often been cited as a mechanism for the shallowing of remanence directions (Ozima, 1980) but is infrequently reported in natural sediments.

\section{Finer Scale Variations in AMS Data}

Although this interpretation broadly fits the data for Hole $671 \mathrm{~B}$, there are a number of anomalous groups of samples that indicate that the grain fabrics response to strain may not be homogeneous over the whole sedimentary sequence.

The AMS in Core 110-671B-7H is of a normal sedimentary type, with $K_{\min }$ near vertical (observed bedding is sub-horizontal) and low $q$-value, showing little sign of a tectonic overprint, except perhaps for the N-S alignment of $K_{\max }$ axes (Figs. 7 and 8 ). This is in contrast to the AMS of the cores on either side, which have a fabric more typical of the rest of the hole (Figs. 7, 8 and Table 1). Two other groups of samples have AMS features that are distinct from the main style of AMS in this hole, and may have interpretations that are related to coring disturbance.

Group 1: Samples from Core 110-671B-lH predominantly have an AMS with $K_{\max }$ near vertical (Fig. 8 and Table 1). Some samples from Cores $110-671 \mathrm{~B}-2 \mathrm{H},-3 \mathrm{H},-4 \mathrm{H}$, and $-6 \mathrm{H}$ also have a fabric with a steeply dipping $K_{\max }$. 


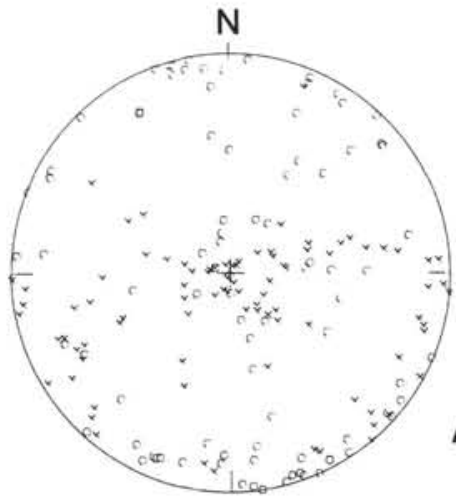

$671 \mathrm{~B}-1 \mathrm{H}$ to $14 \mathrm{X}$

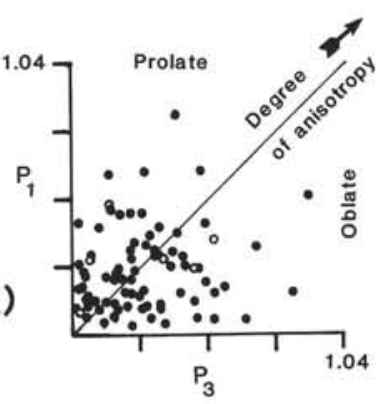

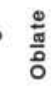

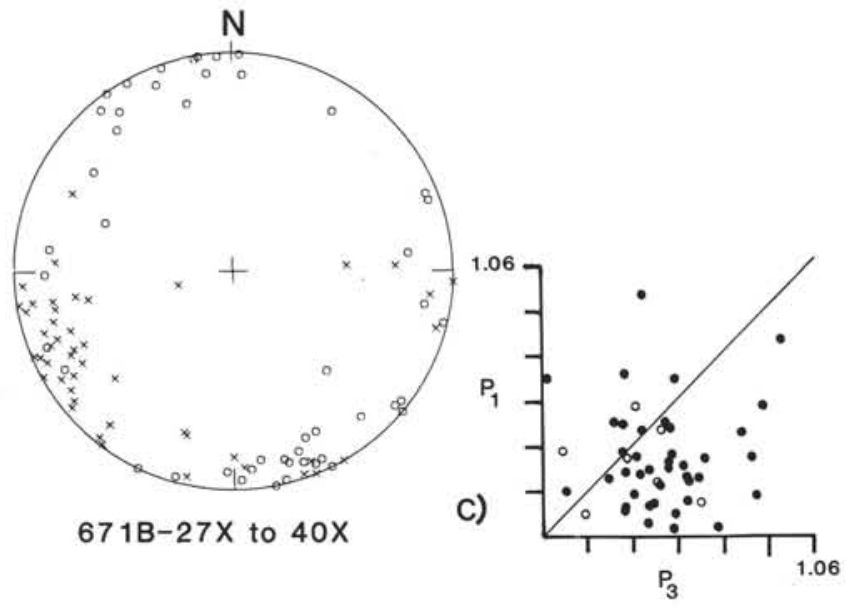

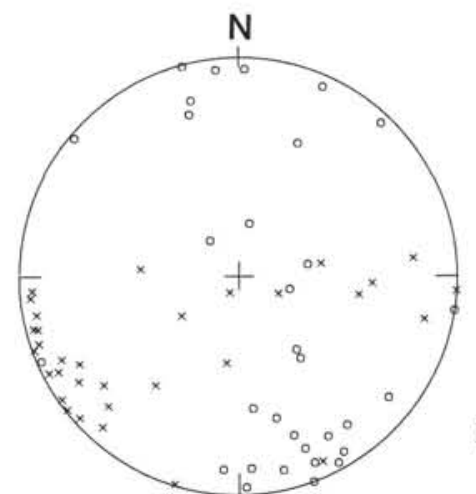

$671 \mathrm{~B}-17 \mathrm{X}$ to $25 \mathrm{X}$

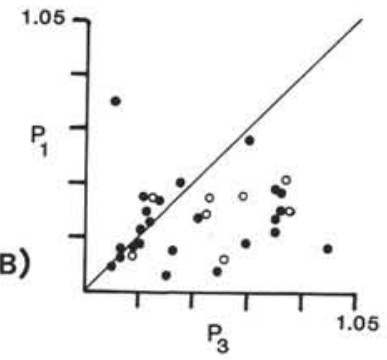

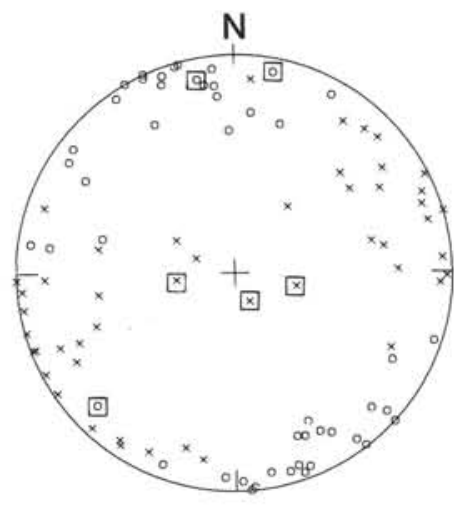

$671 \mathrm{~B}-41 \mathrm{X}$ to $56 \mathrm{X}$

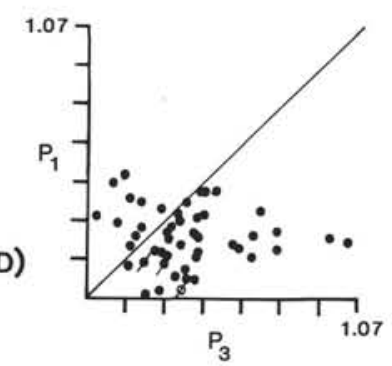

Figure 5. AMS $K_{\max }$ and $K_{\min }$ directions for Hole 671B. Also shown are the axial ratio plots for the groups of cores indicated. Samples possessing scaly fabric are marked with a square on the stereographic projection and a slash on the axial ratio plot. Samples possessing a paramagnetic AMS are indicated with an open circle on the axial ratio plot. The inclined line across the axial ratio plot separates the oblate and prolate susceptibility ellipsoid fields. Crosses $K_{\min }$, circles $K_{\max }$; upper hemisphere equal-area projection.

Table 2. Averaged AMS data for core intervals in Hole 671B.

\begin{tabular}{|c|c|c|c|c|c|c|c|c|c|c|c|c|c|}
\hline \multirow[b]{2}{*}{ Interval } & \multicolumn{4}{|c|}{$K_{\max }$} & \multicolumn{4}{|c|}{$K_{\min }$} & \multirow[b]{2}{*}{$P_{1}$} & \multirow[b]{2}{*}{$P_{3}$} & \multirow[b]{2}{*}{$q$} & \multirow[b]{2}{*}{$h \%$} & \multirow[b]{2}{*}{$\mathrm{n}$} \\
\hline & Dec & $\pm \mathrm{CSD}$ & Inc & $\pm \mathrm{SD}$ & Dec & $\pm \mathrm{CSD}$ & Inc & $\pm \mathrm{SD}$ & & & & & \\
\hline \multicolumn{14}{|l|}{ 671B- } \\
\hline $1 \mathrm{H}-14 \mathrm{X}$ & 174 & 43 & -24 & 26 & 086 & 42 & -42 & 32 & 1.0094 & 1.0104 & 0.73 & 1.9 & 88 \\
\hline $11 X-20 X$ & 165 & 53 & -27 & 24 & 259 & 33 & -35 & 28 & 1.0104 & 1.0143 & 0.59 & 2.5 & 47 \\
\hline $17 X-25 X$ & 162 & 31 & -22 & 23 & 247 & 27 & -22 & 24 & 1.0134 & 1.0209 & 0.57 & 3.1 & 32 \\
\hline $27 X-40 X$ & 156 & 35 & -10 & 9 & 246 & 32 & -14 & 13 & 1.0169 & 1.0271 & 0.54 & 4.3 & 48 \\
\hline $41 X-56 \mathrm{X}$ & 158 & 27 & -11 & 9 & 249 & 28 & -20 & 21 & 1.0162 & 1.0264 & 0.46 & 3.5 & 48 \\
\hline $46 \mathrm{X}-54 \mathrm{X}$ & 161 & 21 & -10 & 8 & 073 & 25 & -25 & 19 & 1.0187 & 1.0227 & 0.66 & 4.0 & 24 \\
\hline $55 \mathrm{X}-56 \mathrm{X}$ & 194 & 25 & -10 & 3 & 109 & 32 & -71 & 5 & 1.0068 & 1.0200 & 0.31 & 2.6 & 3 \\
\hline
\end{tabular}

Group 2: The samples between 90 and 180 mbsf (approximately Cores $110-671 \mathrm{~B}-11 \mathrm{X}$ to $-20 \mathrm{X}$ ) have a preponderance of samples with steep to moderately dipping $K_{\max }$ axes ( $26 \%$ greater than $45^{\circ}$ ). These fall either side of the major thrust at $128 \mathrm{~m}$, with four out of eight samples from Core 110-671B-14X (sampling interval 120.89 to $129.82 \mathrm{mbsf}$ ) possessing $K_{\max }$ inclinations greater than $45^{\circ}$ (Figs. 4 and $5 \mathrm{~A}, 5 \mathrm{~B}$ ).

\section{Interpretation}

Group 1: There are two plausible mechanisms for the production of this fabric: (a) coring disturbance and (b) extensive tectonic shortening. Kent and Lowrie (1974) noted a similar style of AMS in some deep-sea cores, which they attributed to disturbance caused by "flow-in" at the tops and bottoms of pis- ton cores, although the samples here are not necessarily from the tops and bottoms of cores. Conversely, Taira and Niitsuma (1986) suggested that coring disturbance produces a randomizing effect on the AMS, as opposed to the kind of consistent fabric observed here. Several samples from the APC cores at Sites 673 and 674 also have a style of AMS with $K_{\max }$ vertical (Appendix), although these are not concentrated in the first two piston cores, and they seem to have an alternative origin (see below). In addition, the remanent magnetization of Core $110-671 \mathrm{~B}-1 \mathrm{H}$ is inconsistent with significant amounts of coring disturbance (Hounslow et al., this volume).

An AMS with $K_{\max }$ near vertical would be expected after extensive horizontal tectonic shortening (Fig. 6) and could simply be generated by the kind of stress field that evidently has af- 


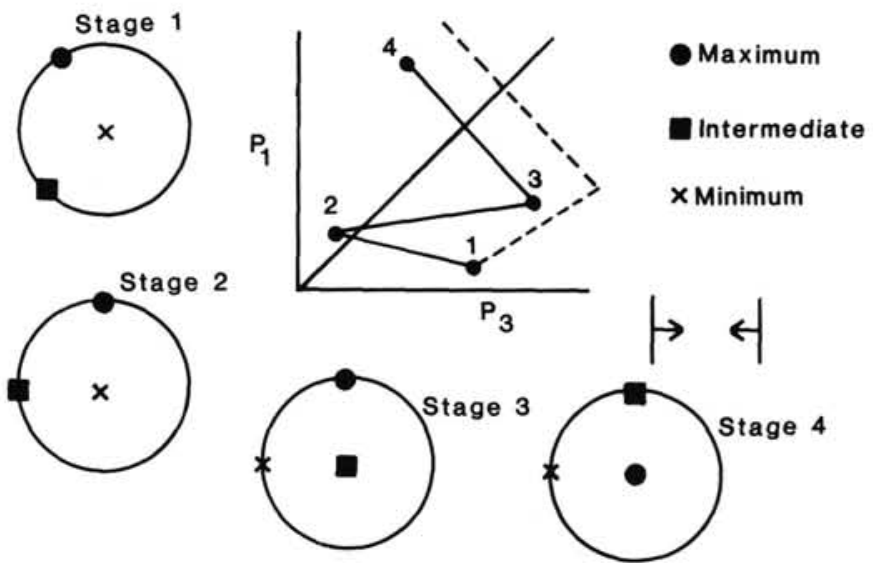

Figure 6. Schematic diagram indicating the evolution of an AMS ellipsoid with progressive horizontal shortening, and the corresponding paths on a $P_{1}-P_{3}$ plot (see text for details). The solid line on the axial ratio plot indicates an original sedimentary AMS, shortened parallel to the bedding, and the dashed line one shortened perpendicular to the bedding plane.

fected the samples from this hole. The weakly consolidated nature of these sediments would favor a more rapid strain rate, under the same stress, than sediments which have undergone more water loss.

Group 2: Two possibilities are suggested in explaining this fabric.

A. Coring disturbance induced by the XCB coring process, the first core of which was taken at 91.6 mbsf (Core 110-671B11X).

B. The strain rate in the sediments either side of the thrust at 128 mbsf may be affected by the mechanics of the thrust propagation. Coring disturbance can be difficult to assess in the rather soft sediment after the last APC core but before well-developed biscuiting in the XCB cores; particularly macroscopically undisturbed material may be microscopically disturbed. Alternatively, the strain rate evolution and the orientation of the stresses may also be affected by the higher pore pressures assumed to be associated with the thrust propagation (Moore et al., 1988).

Both of these problems could be addressed further by resampling at a different site. However, these features together with the anomalous fabric in Core $110-671 \mathrm{~B}-7 \mathrm{H}$ are consistent with the suggestion that the distribution of strain in the overthrust sequence is inhomogeneous, perhaps due to differences in physical properties or the distribution of stress. The highly variable nature of the individual sample AMS shape ellipsoid downhole may also reflect the inhomogeneous nature of the strain (Figs. $4 \mathrm{~A}$ and 7 ).

\section{AMS OF SEDIMENTS WITH SUB-HORIZONTAL SCALY FABRIC}

Scaly fabric is characterized microscopically by thin zones of strong preferred clay orientation adjacent to domains of more randomly oriented clay particles, which are presumably relics of the former fabric. The zones of strong preferred clay orientation correspond to the brittle fractured slip zones evident on broken surfaces of core (Behrmann et al., in press). This fabric appears to develop along low-angle shear zones, which can be the décollement or thrusts within the accreted sequence (Moore et al., 1985; Behrmann and Brown, this volume). The AMS of all samples from Sites 671,673 , and 674 possessing sub-horizontal scaly fabric is shown in Figure 9 (the samples possessing scaly fabric in Hole 671B are in the core interval 110-671B-55X to -56X; Table 2). The cluster of $K_{\min }$ axes and the predominantly oblate shape attests to the well-developed orientation of both ferromagnetic and paramagnetic minerals in the plane of the scalyness (Table 4, Fig. 9).

As the décollement horizon is approached in Hole 671B the strongly oblate AMS progressively changes (albeit sporadically) to one that is triaxial in form (e.g., Cores 110-671B-46X to -54X Fig. $7 \mathrm{C}$ ) and the $h \%$ values peak at about $400 \mathrm{~m}$ and decrease slightly downhole (Fig. 4B). This is thought to indicate that, prior to the macroscopic development of the scaly fabric in the décollement horizon, the sub-horizontal grain orientation characteristic of scaly fabric is progressively overprinted on the oblate fabric style found above 400 mbsf.
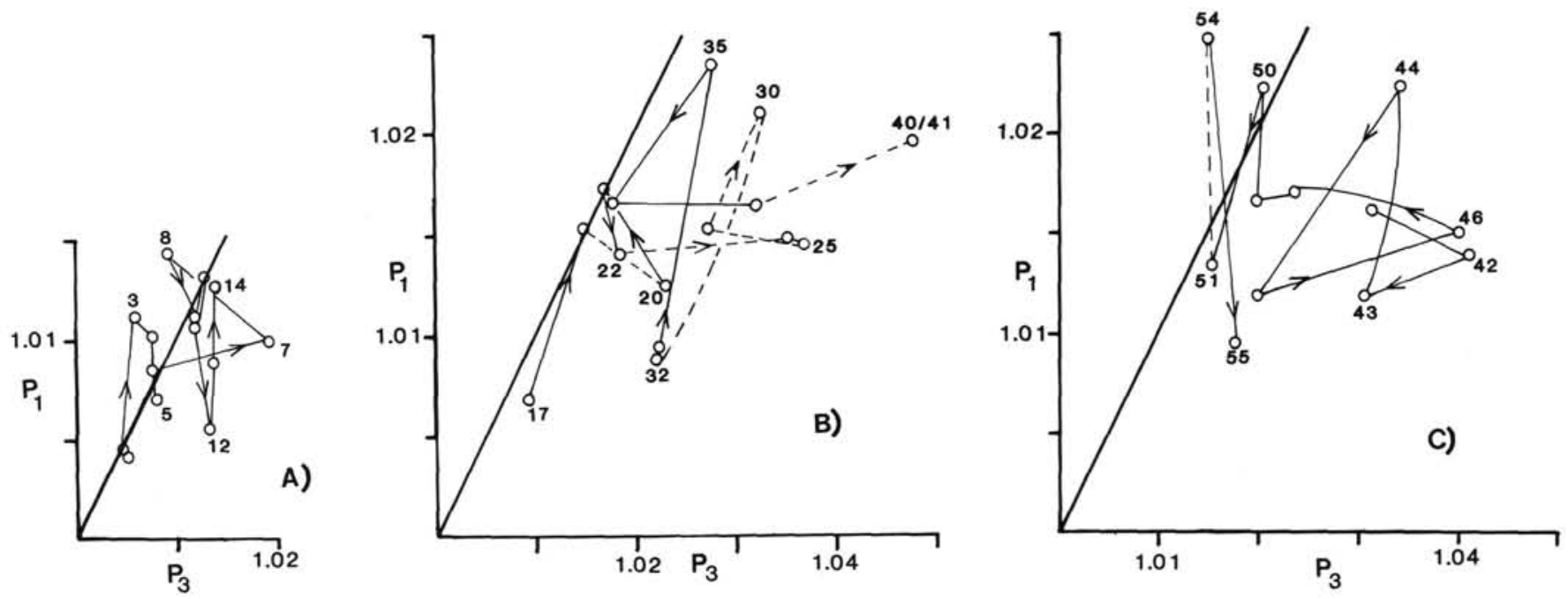

Figure 7. Mean values of $P_{1}$ and $P_{3}$ for cores from Hole 671B shown, on an axial ratio plot. A dashed line connects points not from adjacent cores, and a solid line, adjacent cores. 

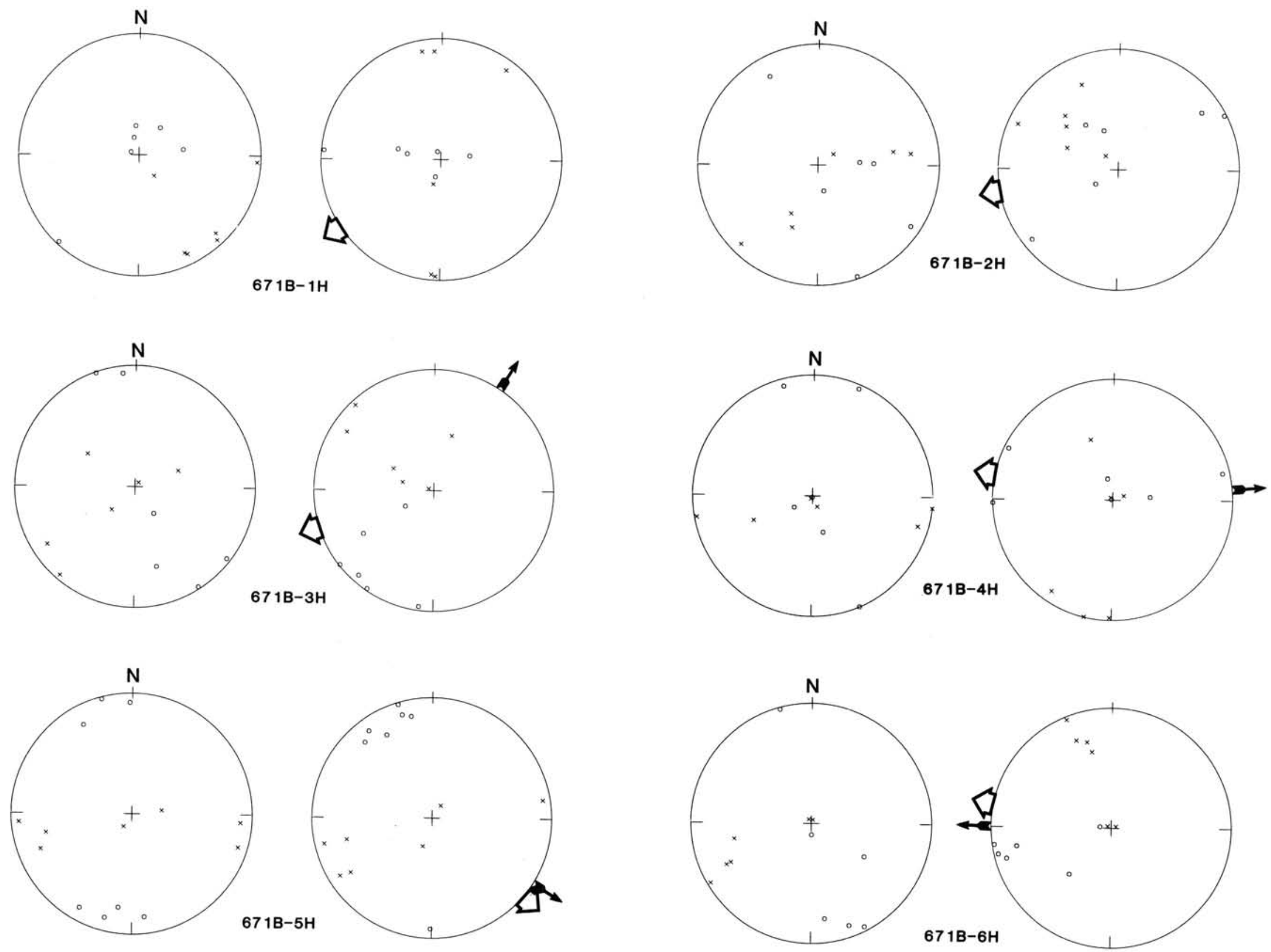

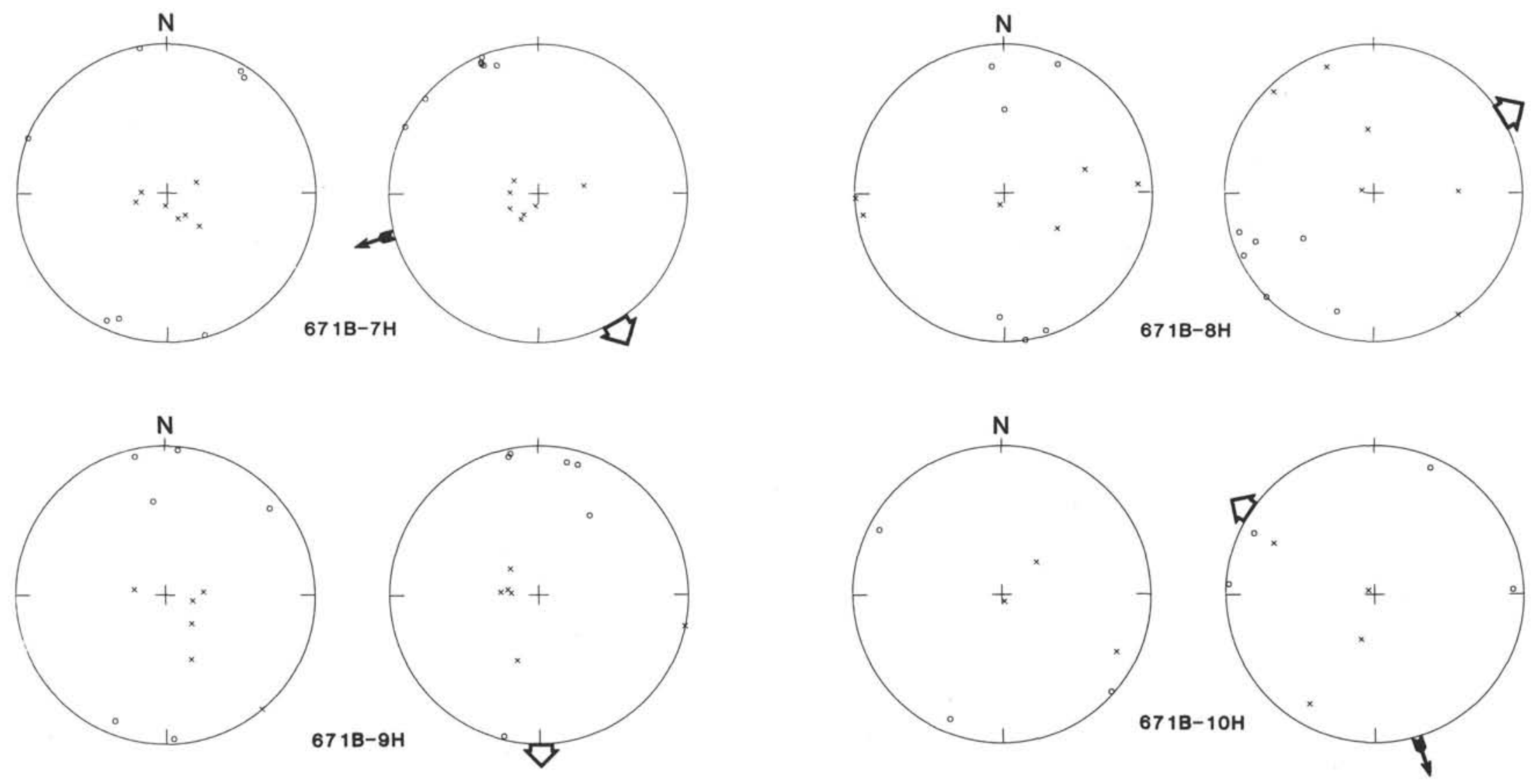

Figure 8. AMS data for all APC cores from Hole 671B. The stereographic projections indicating $\mathrm{N}$ have samples oriented to North using individual sample data; that with no mark is plotted relative to the core liner fiducial. Thick arrows indicate the mean core geomagnetic north direction determined from the remanence data (Hounslow et al., this volume) and the thin arrows the North direction determined with the Eastman-Whipstock multishot orientation device. Crosses $K_{\min }$, circles $K_{\max }$; upper hemisphere equal-area projection. 


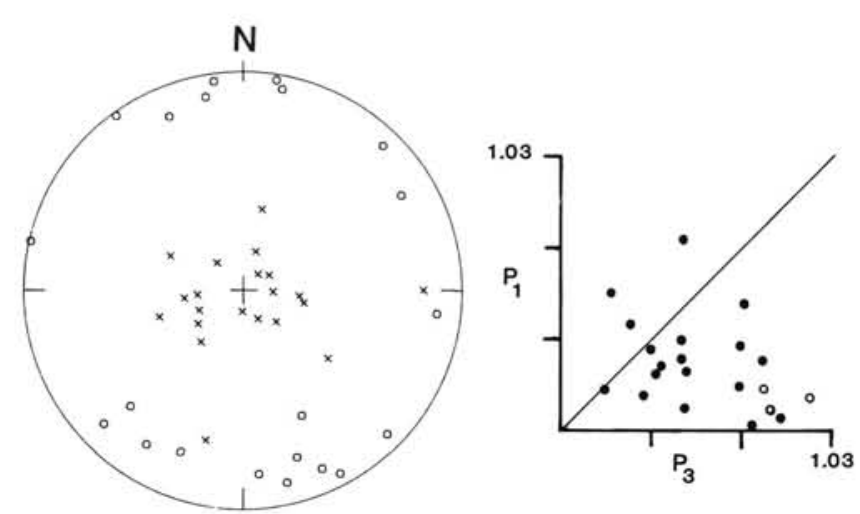

Figure 9. The AMS of all samples possessing sub-horizontal scaly fabric from Holes 671B (Cores 110-671B-55X to -56X), 673B (Core 110-673B$22 \mathrm{X}$ ) and $674 \mathrm{~A}$ (Core 110-674A-13X and most samples from Cores 110674A-26X and -27X), and the axial ratio plot. See Figure 5 for key.

\section{SLOPE SEDIMENTS AT SITES 673 AND 674}

At Sites 673 (Hole 673A, Cores $110-673 \mathrm{~B}-1 \mathrm{H}$ to $-7 \mathrm{X}$ ) and 674 (Cores $110-674 \mathrm{~A}-1 \mathrm{H}$ to $-7 \mathrm{X}$ ) there is a well developed slope sequence which consist of both hemipelagic (Pleistocene to late Pliocene) foraminifers/nannofossil calcareous muds and marls, deposited directly on the slope, mixed with material derived from upslope (Mascle, Moore, et al., 1988; Moore et al., 1988). This upslope derived sediment consists of matrix-supported conglomerates and breccias, and large slump blocks of Miocene claystone. Samples taken from this sequence are from the hemipelagic units and the large slump blocks.

The hemipelagic calcareous muds and marls from Holes $673 \mathrm{~A}, 673 \mathrm{~B}$, and Core $110-674 \mathrm{~A}-1 \mathrm{H}$ have very variable $K_{\min }$ and $K_{\max }$ dips, with a few of the samples possessing steeply dipping $K_{\max }$ axes (Fig. 10A, Table 3). The horizontal bedding and unconsolidated nature of this lithology point to the scatter in the AMS axes being caused by the extensive bioturbation of an otherwise sedimentary fabric (Rees et al., 1982). In addition this scatter may be aided by coring disturbance, and extensive faulting in Hole 673B.

The AMS of Cores $110-674 \mathrm{~A}-5 \mathrm{X}$ to $-7 \mathrm{X}$ is apparently largely of a primary depositional type with $K_{\min }$ axes near vertical (subhorizontal bedding in these cores) and oblate fabrics (Fig. 10C, Table 3), indicating that the deposition of this slope sequence started as early as the uppermost Pliocene (Moore et al., 1988). The poorly defined alignment of the $K_{\max }$ axes in a southeast direction is reminiscent of the AMS deeper in this hole, probably indicating the deformation of the slope sequence.

The Miocene claystone blocks generally have steeply dipping $K_{\min }$ axes and shallow $K_{\max }$ axes clustered in an approximate N$\mathrm{S}$ trend (Fig. 10B, Table 3). The style of AMS is similar to that observed in the upper parts of Hole 671B and appears to be partly of sedimentary origin with a superimposed tectonic fabric. It is not clear whether this fabric was acquired prior to the slump blocks incorporation at its present position, or whether the blocks are currently undergoing shortening, as suggested for the interbedded hemipelagic slope sediments.

\section{ACCRETED SEDIMENTS IN HOLES 673B AND 674A}

The accreted sediments encountered at these two sites are likely to have undergone similar fabric modification to those encountered at Site 671 , as well as more severe fabric modification since their accretion. The complex structural features at these two sites, with both tight folding, extensive development of scaly fabric, and extensive thrust dismembering, may have given
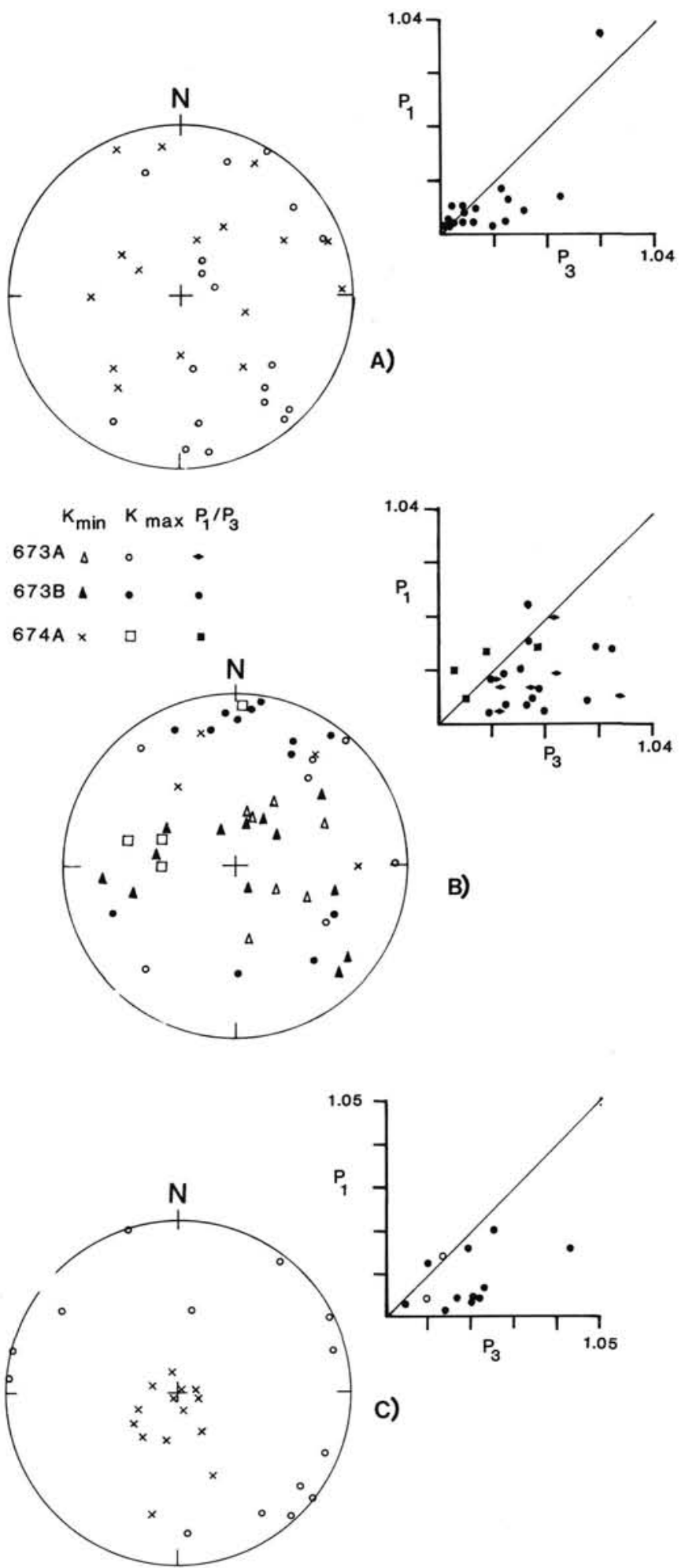

Figure 10. Summary of AMS data from the slope sequences at Sites 673 and 674. A. Hemipelagic foraminifers/nannofossil mudstone and marl of the Pleistocene (sampling intervals $110-673 \mathrm{~A}-1 \mathrm{H}-2,118 \mathrm{~cm}$ to $-673 \mathrm{~A}$ $2 \mathrm{H}-1,57 \mathrm{~cm}$; $110-673 \mathrm{~B}-2 \mathrm{H}-5,90 \mathrm{~cm}$ to $-673 \mathrm{~B}-5 \mathrm{X}-2,90 \mathrm{~cm}$; $110-74 \mathrm{~A}-$ $1 \mathrm{H}-1,75 \mathrm{~cm}$ to $-674 \mathrm{~A}-1 \mathrm{H}-2,117 \mathrm{~cm})$. B. Large Miocene slump blocks (sampling intervals $110-673 \mathrm{~A}-2 \mathrm{H}-4,122 \mathrm{~cm}$ to $-673 \mathrm{~A}-3 \mathrm{H}-4,25 \mathrm{~cm} ; 110-$ $673 \mathrm{~B}-5 \mathrm{H}-3,45 \mathrm{~cm}$ to $-673 \mathrm{~B}-7 \mathrm{X}, \mathrm{CC}, 19 \mathrm{~cm}$ and $110-674 \mathrm{~A}-3 \mathrm{H}-5,20 \mathrm{~cm}$ to $-674 \mathrm{~A}-3 \mathrm{H}-6,44 \mathrm{~cm}$ ), with key to symbols on this plot. C. Pleistocene and Pliocene sequence in interval $110-674 \mathrm{~A}-5 \mathrm{X}-5,15 \mathrm{~cm}$ to $-674 \mathrm{~A}-7 \mathrm{X}-4$, $37 \mathrm{~cm}$. See Figure 5 for key to A and C. 
Table 3. Averaged AMS data for core intervals from the slope sequence at Sites 674 and 673 . The sampling intervals are those indicated in the caption to Figure 10.

\begin{tabular}{|c|c|c|c|c|c|c|c|c|c|c|c|c|c|}
\hline \multirow[b]{2}{*}{ Samples } & \multicolumn{4}{|c|}{$K_{\max }$} & \multicolumn{4}{|c|}{$K_{\min }$} & \multirow[b]{2}{*}{$P_{1}$} & \multirow[b]{2}{*}{$P_{3}$} & \multirow[b]{2}{*}{$q$} & \multirow[b]{2}{*}{$h \%$} & \multirow[b]{2}{*}{$\mathrm{n}$} \\
\hline & Dec & $\pm \mathrm{CSD}$ & Inc & $\pm \mathrm{SD}$ & Dec & $\pm \mathrm{CSD}$ & Inc & $\pm \mathrm{SD}$ & & & & & \\
\hline Plio/Pleis & 354 & 36 & -30 & 23 & 102 & 52 & -36 & 22 & 1.0059 & 1.0089 & 0.55 & 1.5 & 17 \\
\hline $\begin{array}{l}\text { All Slump } \\
\text { Blocks }\end{array}$ & 015 & 43 & -22 & 15 & 010 & 47 & -49 & 17 & 1.0080 & 1.0156 & 0.42 & 2.3 & 24 \\
\hline $\begin{array}{c}\text { 674A-5X- } \\
7 \mathrm{X}\end{array}$ & 125 & 43 & -10 & 13 & 209 & 58 & -70 & 16 & 1.0078 & 1.0172 & 0.49 & 2.4 & 14 \\
\hline \multicolumn{14}{|c|}{ Miocene Slump Blocks in Holes: } \\
\hline $\begin{array}{l}673 A \\
673 B \\
674 A\end{array}$ & $\begin{array}{l}023 \\
004 \\
088\end{array}$ & $\begin{array}{l}26 \\
40 \\
43\end{array}$ & $\begin{array}{l}-20 \\
-19 \\
-39\end{array}$ & $\begin{array}{l}12 \\
11 \\
19\end{array}$ & $\begin{array}{l}189 \\
016 \\
154\end{array}$ & $\begin{array}{l}40 \\
46 \\
54\end{array}$ & $\begin{array}{l}-52 \\
-50 \\
-29\end{array}$ & $\begin{array}{r}8 \\
17 \\
9\end{array}$ & $\begin{array}{l}1.0083 \\
1.0075 \\
1.0089\end{array}$ & $\begin{array}{l}1.0182 \\
1.0162 \\
1.0093\end{array}$ & $\begin{array}{l}0.38 \\
0.34 \\
0.72\end{array}$ & $\begin{array}{l}2.6 \\
2.3 \\
1.8\end{array}$ & $\begin{array}{r}7 \\
13 \\
4\end{array}$ \\
\hline
\end{tabular}

rise to significantly different strain/stress histories in various parts of the sequence.

\section{Hole 673B}

A majority of the samples collected from this sequence had susceptibilities too low to measure the AMS reliably, so that information for this hole is rather scant. The AMS of samples from 110 -Core $673 \mathrm{~B}-22 \mathrm{X}$ to $-25 \mathrm{X}$ probably results from the imposition of a sub-horizontal weakly developed scaly fabric (associated with a low-angle thrust at this level) on an oblate fabric similar to that seen in the lower part of Hole 671B (Fig. 11A, Table 4).

The sediments in Core 110-673B-28X have an AMS carried by paramagnetic minerals, steep bedding dips, and no scaly fabrics, and the mean $h \%$ value is much lower than in similar situations where the anisotropy is carried by titanomagnetite (Fig. 11B, Table 4). The style of this AMS is quite like that found in Core 110-671B-1H, similar to a stage 4 tectonic fabric, although the samples show a mixture of prolate and oblate shapes. The AMS could be generated by approximately E-W shortening superimposed on an E-W oriented vertical oblate fabric, perhaps of bedding origin.

\section{Hole 674A}

Samples from Core $110-674 \mathrm{~A}-11 \mathrm{X}$ to $16 \mathrm{X}$ have a broadly similar AMS (except for those in Core 110-674A-14X). Their similarity probably results largely from the incipient sub-horizontal scaly fabric associated with the out-of-sequence thrust, causing steep but smeared $K_{\min }$ axes (Figs. 12 and 13A), although the only samples possessing scaly fabric are those from Core 110-673B-13X. This group of samples is in a structural setting similar to samples from Cores $110-673 \mathrm{~B}-22 \mathrm{X}$ to $-25 \mathrm{X}$, and have a broadly similar style of AMS.

The AMS of samples from Core 110-674A-14X is quite distinct from that found in cores either side of it (Fig. 13B). The bedding is steeply dipping and the AMS is similar to that found in Core 110-673B-28X, except the trend of the $K_{\min }$ axes are $90^{\circ}$ apart. The core interval is enclosed within a domain of sub-horizontal scaly clays, and may represent an isolated sliver separated by thrusting. The orientation of the AMS axes suggests that it may have a similar compound origin to that indicated for Core 110-673B-28X (Fig. 12B).

The AMS of samples from Cores 110-674A-17X to $-24 \mathrm{X}$ show a poor degree of clustering (Fig. 13C) and, in parts, this interval has moderate to steeply dipping scaly fabric and steep bedding dips. The samples grouped as cores show a smearing of $K_{\max }$ and $K_{\min }$ axes along the same inclination, as if the orientation to geomagnetic north has introduced considerable scatter into an original in-situ cluster of AMS axes.

The cluster of $K_{\min }$ axes close to vertical in Cores 110-674A$25 \mathrm{X}$ to $-28 \mathrm{X}$ reflects the well-developed horizontal scaly fabric
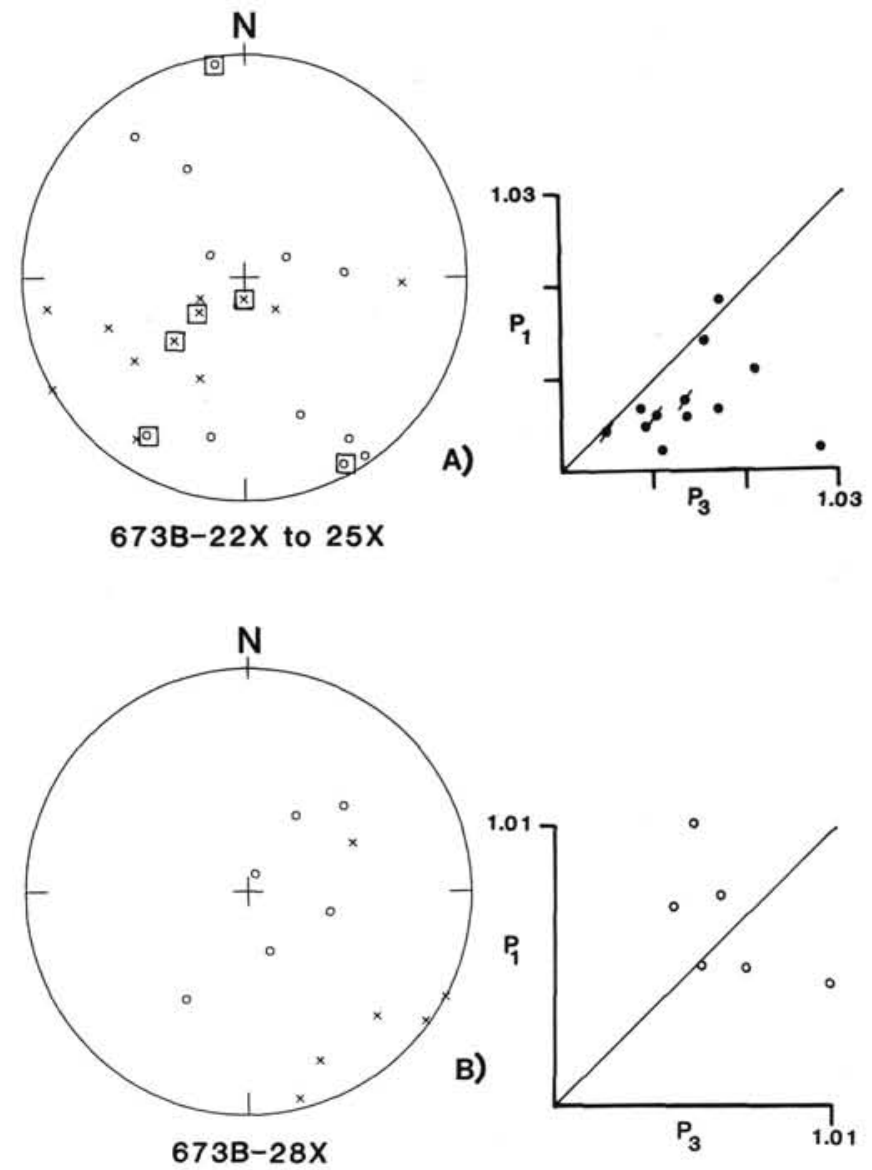

Figure 11. AMS data for the accreted sequence in Hole 673B, and axial ratio plots (see Figure 5 for key).

in Cores 110-674A-26X and -27X, associated with the out-of-sequence thrust at this level (Fig. 13D). In Cores 110-674A-33X to $-37 \mathrm{X}$, steep to moderately dipping scaly fabric is present that is reflected in the steep inclination of the $K_{\max }$ axes (Fig. 13E). Steeply dipping scaly fabric is also found in some of the samples in Cores $110-674 \mathrm{~A}-43 \mathrm{X}$ to $-48 \mathrm{X}$, although shallowly dipping $K_{\max }$ axes are found in those samples not possessing scaly fabric.

Grouped samples possessing steeply dipping scaly fabric show a clear cluster of $K_{\max }$ axes which are nearly vertical (Fig. 14C). This clustering probably reflects the development of further tectonic shortening superimposed on the AMS of the scaly fabric that was presumably generated horizontally but is now sub-ver- 
Table 4. Averaged AMS data for core intervals from the accreted sequence at Sites 673 and 674 . The data for the subhorizontal scaly fabric also include samples from Hole 671B with this fabric (i.e., interval 110-671B-55X to -56X, Table 2). All other data for the NRM oriented fabrics are the same as the corresponding cored interval in the data above.

\begin{tabular}{|c|c|c|c|c|c|c|c|c|c|c|c|c|c|}
\hline \multirow{2}{*}{$\begin{array}{l}\text { Samples/ } \\
\text { interval }\end{array}$} & \multicolumn{4}{|c|}{$K_{\max }$} & \multicolumn{4}{|c|}{$K_{\min }$} & \multirow[b]{2}{*}{$P_{1}$} & \multirow[b]{2}{*}{$P_{3}$} & \multirow[b]{2}{*}{$q$} & \multirow[b]{2}{*}{$h \%$} & \multirow[b]{2}{*}{$\mathrm{n}$} \\
\hline & Dec & $\pm \mathrm{CSD}$ & Inc & $\pm \mathrm{SD}$ & Dec & \pm CSD & Inc & $\pm \mathrm{SD}$ & & & & & \\
\hline \multicolumn{14}{|l|}{ 673B- } \\
\hline $22 \mathrm{X}-25 \mathrm{X}$ & 154 & 37 & -31 & 24 & 236 & 31 & -44 & 26 & 1.0076 & 1.0142 & 0.44 & 2.2 & 12 \\
\hline $28 \mathrm{X}$ & 028 & 42 & -59 & 15 & 135 & 32 & -16 & 16 & 1.0065 & 1.0062 & 0.71 & 1.3 & 6 \\
\hline 674A- & & & & & . & & & & & & & & \\
\hline $\begin{array}{l}11 X, 12 \mathrm{X} \\
13 \mathrm{X}, 15 \mathrm{X} \\
16 \mathrm{X}\end{array}$ & 159 & 39 & -19 & 11 & 111 & 58 & -52 & 21 & 1.0098 & 1.0138 & 0.58 & 2.4 & 12 \\
\hline $14 \mathrm{X}$ & 322 & 47 & -68 & 9 & 222 & 32 & -9 & 6 & 1.0129 & 1.0124 & 0.72 & 2.9 & 7 \\
\hline $17 X-24 X$ & 086 & 39 & -33 & 15 & 141 & 61 & -33 & 17 & 1.0115 & 1.0180 & 0.56 & 2.9 & 22 \\
\hline $25 X-28 X$ & 011 & 63 & -20 & 19 & 036 & 49 & -55 & 20 & 1.0081 & 1.0229 & 0.48 & 2.3 & 18 \\
\hline $33 \mathrm{X}-37 \mathrm{X}$ & 316 & 52 & -43 & 25 & 111 & 47 & -36 & 24 & 1.0163 & 1.0235 & 0.57 & 4.0 & 14 \\
\hline $43 X-48 X$ & 266 & 44 & -33 & 24 & 173 & 58 & -29 & 17 & 1.0160 & 1.0173 & 0.70 & 3.2 & 23 \\
\hline \multirow{2}{*}{$\begin{array}{l}\text { Horiz scaly } \\
\quad 671,673,674\end{array}$} & & & & & & & & & & & & & \\
\hline & 175 & 39 & -13 & 9 & 078 & 49 & -66 & 16 & 1.0066 & 1.0148 & 0.40 & 2.3 & 21 \\
\hline \multicolumn{14}{|l|}{ Non-scaly } \\
\hline $673 B$ & 150 & 51 & -44 & 23 & 063 & 52 & -26 & 21 & 1.0070 & 1.0191 & 0.50 & 1.9 & 17 \\
\hline \multicolumn{14}{|l|}{ Non-scaly } \\
\hline $674 \mathrm{~A}$ & 286 & 53 & -35 & 23 & 019 & 68 & -33 & 18 & 1.0114 & 1.0163 & 0.60 & 2.7 & 44 \\
\hline \multicolumn{14}{|l|}{ Sub-vert } \\
\hline Scaly, 674A & 273 & 54 & -40 & 23 & 162 & 65 & -32 & 20 & 1.0166 & 1.0190 & 0.65 & 3.5 & 36 \\
\hline \multirow{2}{*}{\multicolumn{14}{|c|}{$\begin{array}{l}\text { NRM Oriented } \\
674 \mathrm{~A} \text { - }\end{array}$}} \\
\hline & & & & & & & & & & & & & \\
\hline $25 \mathrm{X}-28 \mathrm{X}$ & 130 & 53 & & & 193 & 45 & & & & & & & \\
\hline $\begin{array}{l}11 \mathrm{X}, 12 \mathrm{X} \\
13 \mathrm{X}, 15 \mathrm{X} \\
16 \mathrm{X}\end{array}$ & 358 & 37 & & & 124 & 40 & & & & & & & \\
\hline
\end{tabular}

tical. The clearly defined dip of the $K_{\max }$ axes to the west may reflect the dip direction of the scaly fabric or perhaps the extension direction. The similarity of this AMS to that from samples not possessing scaly fabric (Fig. 14B) may indicate that a large part of the accreted sequence in Hole 674A, away from the outof-sequence thrusts, may have had a similar strain history.

\section{Orientation Using Uncleaned Remanence Directions}

The method of core orientation used so far in this analysis has assumed that the high-coercivity remanent magnetization component represents the geomagnetic field. The clustering of the AMS axes suggests that this is broadly correct, if one assumes some degree of directional consistency of the in-situ fabrics. Hounslow et al. (this volume) suggest that the remanence is strongly influenced by a remagnetisation process in the recent geomagnetic field, with some preservation of a previous magnetization. Because of this, the natural remanent magnetization (NRM) direction might reflect, to a larger degree, the current geomagnetic field direction in samples from the accreted sequence. The NRM direction was therefore used in a trial attempt to gain a better azimuthal orientation of the AMS axes. The AMS axes of all data from Holes 674A and 673B were reoriented in this way. The reoriented data, when broken down into the same groupings, showed no significant improvement to clustering or changes to the AMS axes distributions, except for Cores $110-674 \mathrm{~A}-11 \mathrm{X}$ to $-16 \mathrm{X}$ and $110-674 \mathrm{~A}-25 \mathrm{X}$ to $-28 \mathrm{X}$ from the zones of horizontal scaly fabric (Fig. 15, Table 4).

The consistent displacement of the $K_{\min }$ axes of those samples possessing sub-horizontal scaly fabric to the southern side of vertical (Fisher mean of $K_{\min }$ is $150^{\circ},-72^{\circ}$ ), suggests that the scaly fabric, and presumably also the out-of-sequence thrusts may be dipping $10^{\circ}$ to $20^{\circ}$ in a southerly direction (Fig. 15). Also evident in these data are NW-SE and NE-SW trends in the
$K_{\max }$ axes, which are also reflected in other data from the accreted sequence at Sites 673 and 674 (Fig. 14, Table 4).

\section{FABRIC DEVELOPMENT IN THE BARBADOS ACCRETIONARY COMPLEX-CONCLUSIONS}

These measurements, although limited to the samples from the overthrust sequence behind the deformation front, indicate the extensive fabric modification that occurs by incorporating relatively high-porosity sediments into the prism toe. An interpretive summary diagram is shown in Figure 16.

\section{Initial Accretion}

During initial accretion the fabric of the overthrust sedimentary sequence is significantly modified by the stress field set up by the horizontal compressive force of plate collision. The tectonic fabric generation occurs throughout the sequence above the décollement, and is observed in sediments that have no macroscopic evidence of fabric disruption (Fig. 16). The AMS observed at depth in Hole 671B is similar to that seen in rocks on land with a slaty cleavage and in excess of $20 \%$ shortening (Borradaile and Tarling, 1981), although to compare the two is probably unwarranted because the grain deformation mechanism may be quite different (Hrouda, 1987; Owens, 1974). The type of AMS generated depends upon the fabric prior to tectonic shortening and its relative orientation to the shortening direction, as well as depending upon the amount of shortening. There are also indications in the data from the top cores of Hole $671 \mathrm{~B}$, and from adjacent to the major thrust at $128 \mathrm{mbsf}$, that potentially reduced resistance to stress, through high moisture content and pore pressure(?) respectively, has lead to a larger strain rate, and corresponding evolution of the AMS ellipsoid (Fig. 16). 
q

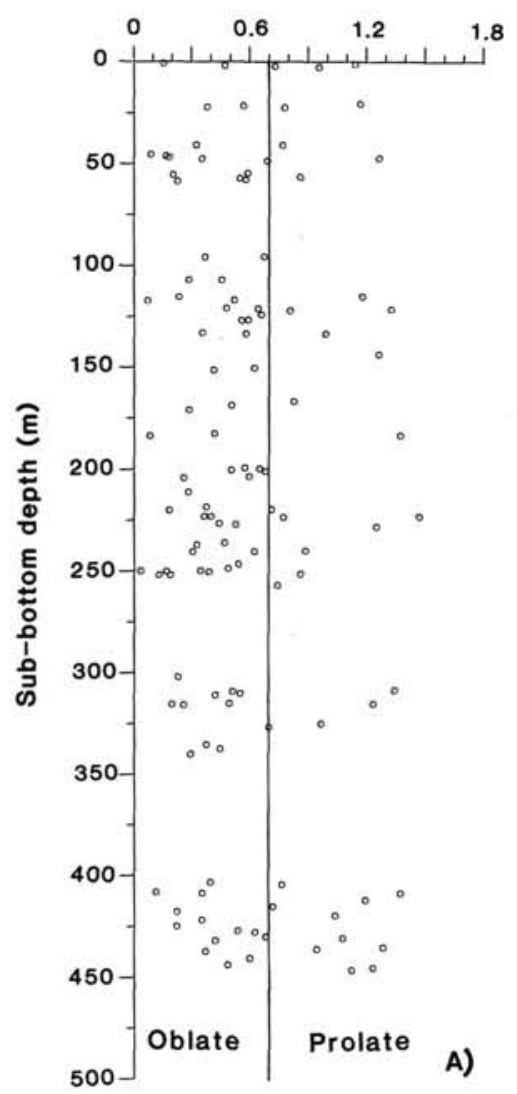

$h \%$

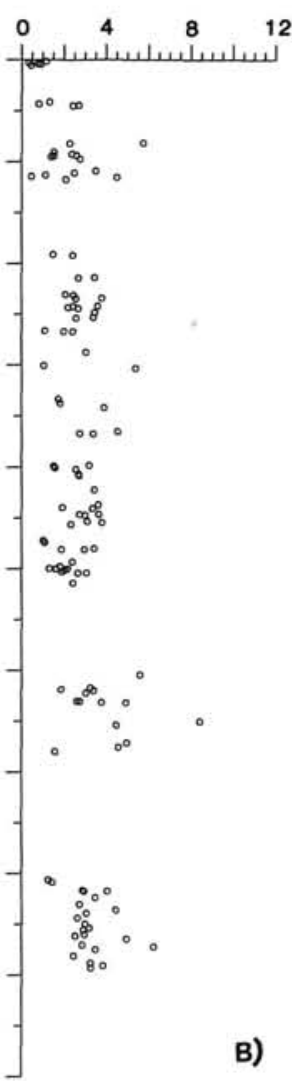

$\mathrm{K}_{\min }$ Inclination

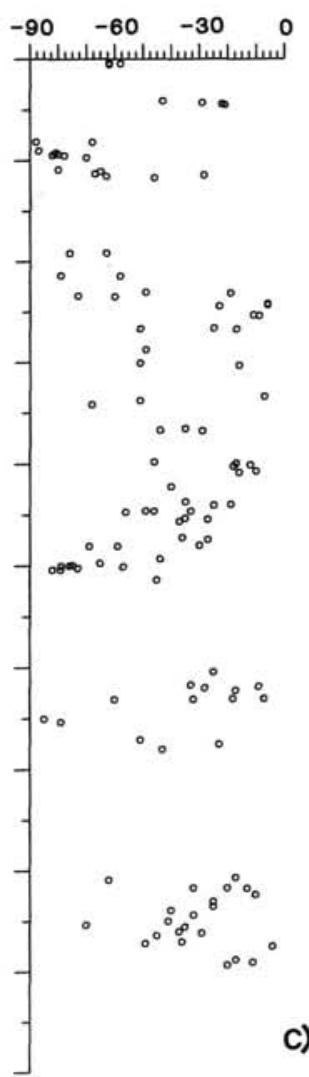

$\mathrm{K}_{\text {max }}$ Inclination

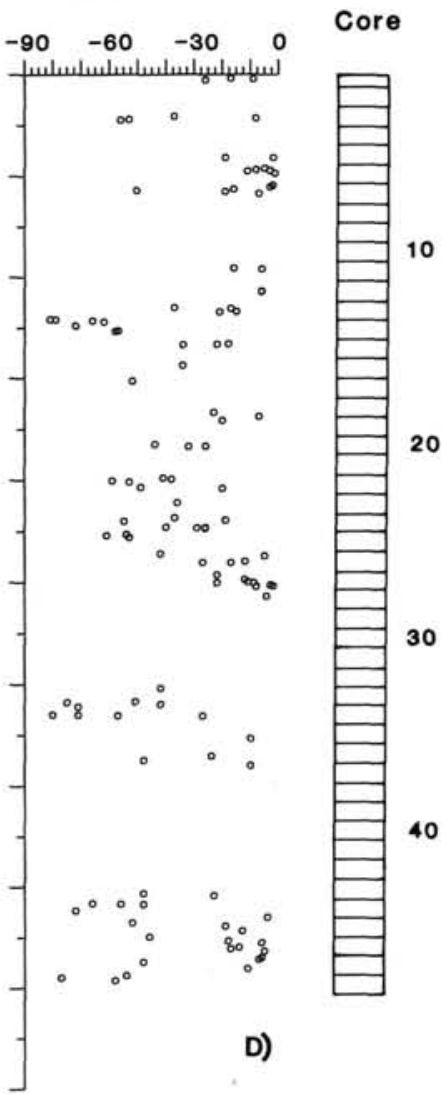

Figure 12. AMS data from Hole 674A plotted relative to sub-bottom depth. AMS axial magnitude parameters, A) $q$ and B) $h \%$. C) $K_{\min }$ and D) $K_{\max }$ are axis inclinations. The corresponding core numbers are also shown.

A similar style of AMS as that seen in Hole 671 was also identified by Taira and Niitsuma (1986) in the Nankai Trough accretionary complex. This was similar to that found above 128 mbsf in this hole, which is structurally equivalent to the same interval sampled by Taira and Niitsuma.

\section{Progressive Deformation}

It is clear that even though off-scraped sediments quickly acquire a tectonic overprint, this is further modified by later deformation. This overprint can result from incorporation into a thrust or the décollement, where the development of a sub-horizontal scaly fabric produces an oblate AMS with the $K_{\min }$ normal to the plane of the scalyness (Fig. 16). This AMS fabric associated with scaly clays may be progressively acquired prior to the macroscopic development of the scalyness. This is hinted at in the cores just above the décollement in Hole 671B and in samples without scaly fabric from the low-angle thrust zones in Holes 674A and 673B.

The hemipelagic sediments deposited on the slope at Sites 674 and 673 generally retain most of their original sedimentary fabric, although the E-W tectonic shortening causes fabric modification of both the hemipelagic and probably also the slumped sediments, indicating the progressive shortening of the slope sequence (Fig. 16). The fabrics generated by initial accretion are relatively simple compared to the multiple phases of fabric generation that occurred in the accreted sequence at Sites 673 and 674. This complex fabric is due to the imposition of AMS generated by further tectonic shortening onto tectonic fabrics developed earlier in accretion. It is probably doubtful that any relic of the original sedimentary fabric is left by this late stage. The steeply dipping scaly clays, which have presumably been tilted from the sub-horizontal position where they formed, have been further strained, leading to an AMS with steeply dipping $K_{\max }$ axes. The non-scaly clays interbedded with the scaly horizons also seem to have a similar AMS, indicating a similar strain history, but without the development of the penetrative fracture (Fig. 16). This may be due to the progressive overprint of the AMS typical of scaly clays onto adjacent non-scaly clays by the associated deformation that appears to generate this characteristic texture. Indeed, this has been suggested for the sequence directly above the décollement in Hole 671A.

The structural grain reflected in the declination distribution of the AMS axes shows a change from the sites where initial accretion occurs to later deformation at Sites 673 and 674. The NNW-SSE, WSW-ENE trend of the $K_{\max }$ and $K_{\min }$ axes at Site 671 , to one which is more NW-SE and NE-SW at Sites 674 and 673 (e.g., Figs. 5 and 14). This trend may also be reflected in the down hole differences in the mean $K_{\max }$ axis values at Site 671 (Table 2), and also perhaps at Sites 673 and 674, where the slope sediments (except Cores 110-674A-5X to -7X) show a more N-S trend of $K_{\max }$ axes (Tables 3 and 4, Fig. 10).

As well as the N-S structural trend seen in the surface topography at the toe of the prism, Fontas et al. (1984) identify a NW-SE structural grain that they suggest is caused by later reverse faults, perhaps the surface expression of the out-of-sequence thrusts identified in Holes 673B and 674A. This would tie in with the pattern of AMS axes trends seen in the accreted sequence. The common directions suggest that in the vicinity of 

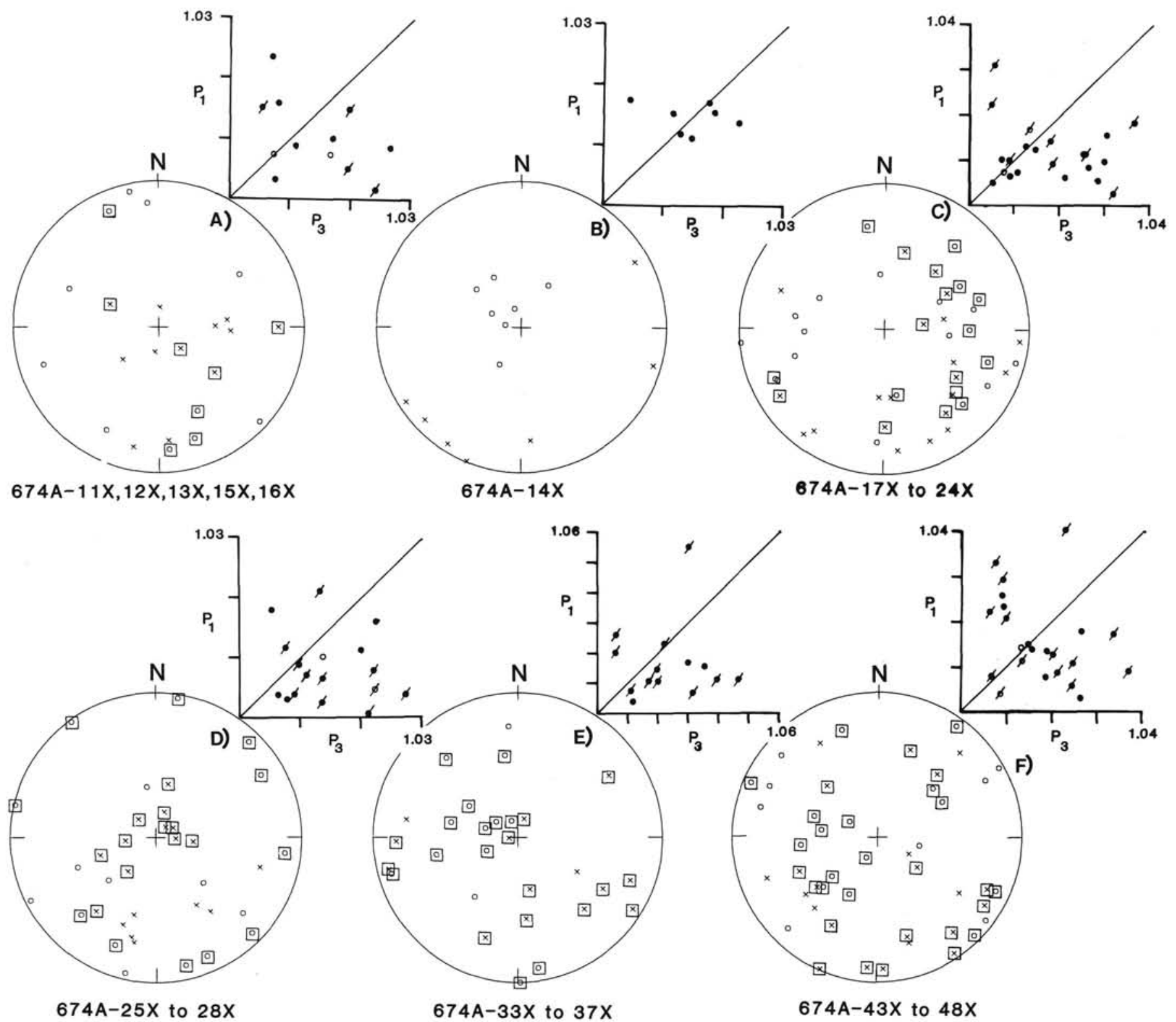

Figure 13. AMS data for the accreted sequence in Hole 674A, and axial ratio plots (see Fig. 5 for key).

the ODP/DSDP sites the maximum stress direction may change trend down section, from a predominantly E-W trend near the surface to one that is more NE-SW at depth. This direction change is explainable in terms of the strong influence of the Tiburon Rise on the deformation style of the prism (Mauffret et al., 1984; Westbrook et al., 1984). The influence of such features may be greater nearer to the basement.

\section{IMPLICATIONS}

The complexity of the magnetic fabric at Sites 673 and 674 is partly a result of the complicated structural folding and thrusting, whereas a terrain in which the style of deformation is much more open, such as the southern part of the Barbados Ridge (Westbrook et al., 1984), may lead to a fabric that is more simply related to strain and bedding features. AMS is evidently a sensitive indicator of the deformation in these deep-sea sediments, and as such it would be possible to document the extent and amount of oceanward deformation and fabric disruption that may occur in sediments forward of the frontal thrusts and in the underthrust sequence, neither of which were sampled in this study. In view of the extensive tectonic fabric overprint on the sediments involved in initial accretion, this fabric disruption may be felt some distance in advance of the deformation front. The first indications of deformation would be a rotation of the $K_{\max }$ axis to parallel the trench axis, so that fabric palaeocurrent studies in trench settings ahead of the macroscale deformation may need careful interpretation.

The indications are that basement features and the plate collision direction may exert control on the structural trends of the prism, which as a result may show considerable along-strike and downhole differences in the trend of the structural grain. The impact of a transverse basement feature during the initial accretion or later deformation of the sediments forming Barbados Island could have given rise to the structural grain observed on Barbados, which is oblique to the trend of the present deformation front. 

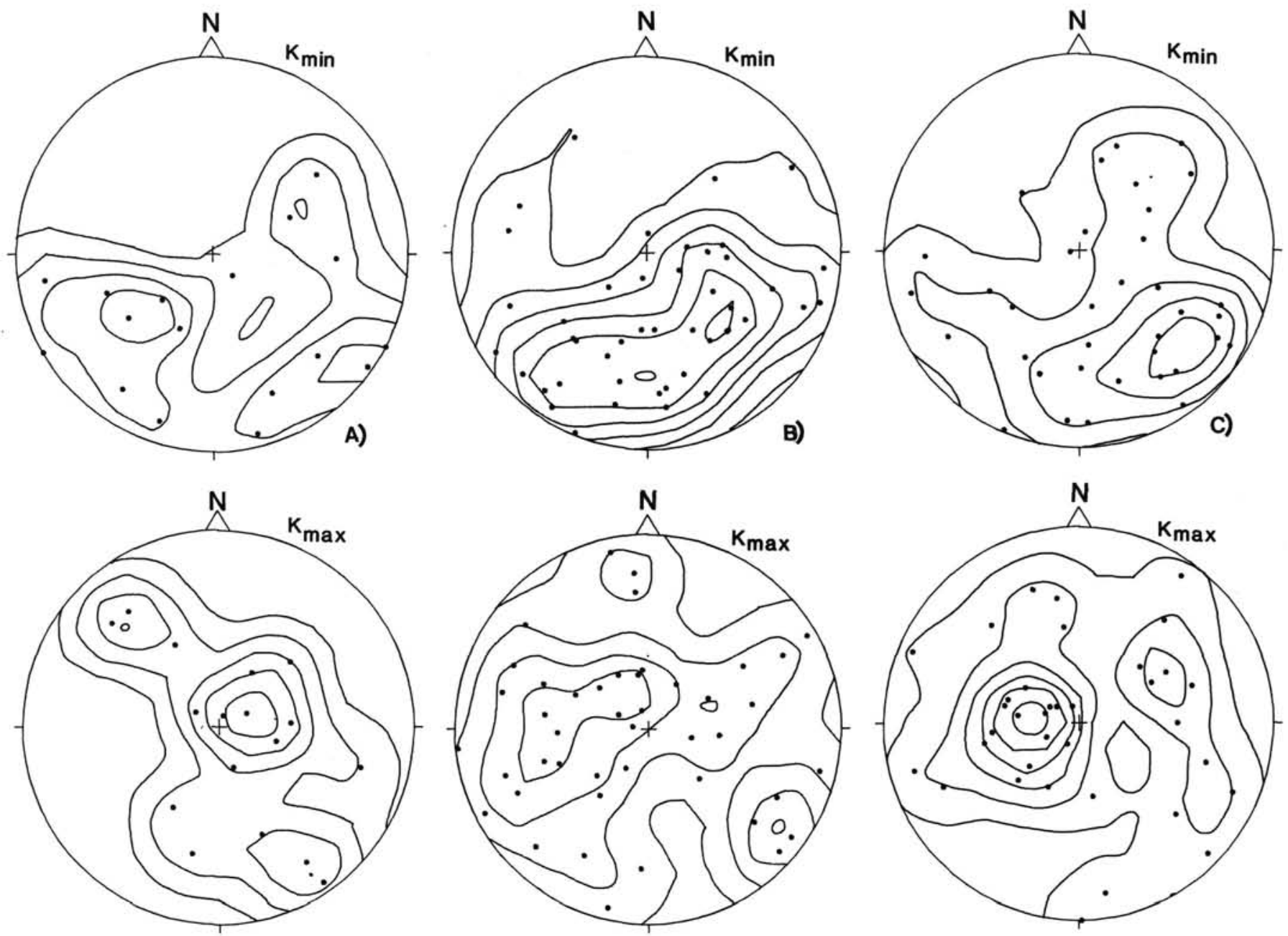

Figure 14. Contoured equal-area stereographic projection of $K_{\max }$ and $K_{\min }$ axes for samples from Holes A) 673B and B) 674A without visible evidence of scaly fabric, and C) samples from Hole $674 \mathrm{~A}$ with steeply dipping scaly fabric.

\section{ACKNOWLEDGMENTS}

This work was partly performed with funding from NERC. Gill Whyman and Paul Bootes undertook some of these measurements. Ernie Hailwood provided the use of the high-field torque magnetometer at the Department of Oceanography, Southampton University. Mark Noel provided helpful comments on an earlier draft of this manuscript and Mark Rudnicki supplied the contouring package.

\section{REFERENCES}

Behrmann, J. A., Brown, K., Moore, J. C., Mascle, A., Taylor, E., Andreiff, P., Alvarez, F., Barnes, R., Beck, C., Blanc, G., Clark, M., Dolan, J., Fisher, A., Gieskes, J., Hounslow, M. W., McLellan, P., Moran, K., Ogawa, V., Sakai, T., Schoonmaker, J., Vrolijk, P., Wilkens, R., and Williams, C., 1988. Evolution of structures and fabrics in the Barbados accretionary prism: insights from Leg 110 of the Ocean Drilling Program. J. Struc. Geol., 10:577-591.

Belderson, R. H., Kenyon, N. H., and Stride, A. H., 1984. Morphology and structural trends of the Barbados Ridge complex in the vicinity of Deep Sea Drilling Project Sites 541, 542 and 543, as revealed by Gloria long-range side-scan sonar. In Buju-Duval, B., Moore, J. C., et al., Init. Repts. DSDP, 78A: Washington (U.S. Govt. Printing Office), 79-81.

Borradaile, G. A., and Tarling, D. H., 1981. The influence of deformation mechanisms on magnetic fabrics in weakly deformed rocks. Tectonophysics, 77: 151-168.

Brown, K. M., and Westbrook, G. K., 1987. The tectonic fabric of the Barbados Ridge accretionary complex. Mar. Pet. Geol., 4:71-81.
Collinson, D. W., 1983. Methods in Palaeomagnetism and Rock Magnetism: London (Chapman \& Hall).

Ellwood, B. B., and Ledbetter M. T., 1977. Antarctic bottom water fluctuations in the Vema Channel: effects of velocity changes on particle alignment and size. Earth Planet. Sci. Lett., 35:189-198.

Fontas, P., Valery, P., Le Quallec, P., Mascle, A., Renard, V., Tardy, M., and Buju-Duval, B., 1984. Multibeam bathymetric survey of the Leg 78A drilling area and comparison with the southern part of the Barbados Ridge deformation front. In Buju-Duval, B., and Moore, J. C., et al., Init. Repts. DSDP, 78A: Washington (U.S. Govt. Printing Office), 63-78.

Graham, J. W., 1966. Significance of magnetic anisotropy in Appalachian sedimentary rocks. In Steinhart, J. S., and Smith, T. J. (Eds.), The Earth Beneath the Continents. Geophys. Monogr., 10:627-648.

Hailwood, E. A., Kidd, R.. B., and Dowling, L., 1987. The magnetic fabric of Neogene and Quaternary sediments on the Feni and Gardar drifts, Northeastern Atlantic, Deep Sea Drilling Project Sites 610 and 611. In Ruddiman, W. F., Kidd, R. B., et al., Init. Repts. DSDP, 94: Washington (U.S. Govt. Printing Office), 1083-1088.

Hamilton, N., and Rees, A. I., 1970. The use of magnetic fabric in palaeocurrent estimation. In Runcorn, S. K. (Ed.). Palaeogeophysics: London (Academic Press), 445-464.

Henry, B., and Daly, L., 1983. From qualitative to quantitative magnetic anisotropy analysis: the prospects of finite strain calibration. Tectonophysics, 98:327-336.

Hounslow, M. W., 1985. Magnetic fabric arising from paramagnetic phyllosilicate minerals in mudrocks. J. Geol. Soc. London, 142: 995-1006. 
Hounslow, M. W., Bootes, P. A., and Noel, M., 1988. Sensitivity and sample shape related measuring effects on the MOLSPIN susceptibility anisotropy meter. Geophys. J. R. Astron. Soc., 94:335-363.

Hrouda, F., 1982. Magnetic anisotropy of rocks and its application in geology and geophysics. Geophys. Surv, 5:37-82.

Hrouda, F., 1987. Mathematical model relationships between the paramagnetic anisotropy and strain in slates. Tectonophysics, 42:323-327.

Hrouda, F., and Janak, F., 1976. The changes in shape of the magnetic susceptibility ellipsoid during progressive metamorphism and deformation. Tectonophysics, 34:135-148.

Kent, D. V., and Lowrie, W., 1974. Origin of magnetic instability in sediment cores from the central North Pacific. J. Geophys. Res., 79: 2987-3000.

Okligfield, R., Lowrie, W., and Dalziel, I.W.D., 1977. Magnetic susceptibility anisotropy as a strain indicator in the Sudbury Basin, Ontario. Tectonophysics, 40:287-308.

Kligfield, R., Owens, W. H., and Lowrie, W., 1981. Magnetic susceptibility anisotropy, strain and progressive deformation in Permian sediments from the Maritime Alps (France). Earth Planet. Sci. Lett., 55:181-189.

Mardia, K. V., 1972. Statistics of Directional Data: New York (Academic Press).

Mascle, A., Biju-Duval, B., de Clarens, P., and Munsch, H., 1986. Growth of accretionary prisms: tectonic processes from Caribbean examples. In Wezel, F. C. (Ed.), The Origin of Arcs: Amsterdam (Elsevier), 375-400.

Mascle, A., Moore, J. C., et al., 1988. Proc. ODP, Init. Repts., 110: College Station, TX (Ocean Drilling Program).

Mauffret, A., Westbrook, G. K., Truchan, M., and Ladd, J., 1984. The relief of the oceanic basement and the structure of the front of the accretionary complex in the region of Sites 541, 542, and 543. In Buju-Duval, B., Moore, J. C., et al., Init. Repts. DSDP, 78A: Washington (U.S. Govt. Printing Office), 49-62.

Moore, J. C., Cowan, D. S., and Karig, D. E., 1985. Structural styles and deformation fabrics of accretionary complexes. Geology, 13: 77-79.

Moore, J. C., Mascle, A., Taylor, E., Andreiff, P., Alvarez, F., Barnes, R., Beck, C., Behrmann, J. H., Blanc, G., Brown, K., Clark, M., Dolan, J., Fisher, A., Gieskes, J., Hounslow, M. W., McLellan, P., Moran, K., Ogawa, Y., Sakai, T., Schoonmaker, J., Vrolijk, P., Wilkens, R., and Williams, C., 1988. Tectonics and hydrogeology of the Northern Barbados Ridge: Results from Leg 110 ODP. Geol. Soc. Am. Bull, 100:578-593.

Ngokwey, K., 1984. Numerical modelling of sediment deformation linked to subduction: mechanical model and comparison with the Barbados Ridge. In Buju-Duval, B., and Moore, J. C., et al., Init. Repts. DSDP, 78A: Washington (U.S. Govt. Printing Office), 559568.

Owens, W. H., 1974. Mathematical model studies on factors affecting the anisotropy in deformed rocks. Tectonophysics, 24:115-131.

Owens, W. H., and Bamford, D., 1976. Magnetic, seismic and other anisotropic properties of rock fabrics. Philos. Trans. R. Soc. London, 283A:55-68.

Ozima, M., 1980. Effects of plastic deformation on the remanent magnetisation of a Cu-Co alloy. Earth Planet Sci. Lett., 47:121-123.

Rees, A. I., 1965. The use of anisotropy of magnetic susceptibility in the estimation of sedimentary fabric. Sedimentology , 4:257-271.

Rees, A. I., Brown, C. M., Hailwood, E. A., and Riddy, P. J., 1982. Magnetic fabric of bioturbated sediment from the Northern Rockall Trough: Comparison with modern currents. Mar. Geol., 46:161-173.

Speed, R. C., 1983. Structure of the accretionary complex of Barbados, 1: Chalky Mount. Geol. Soc. Am. Bull., 94:92-116.

Stacey, F. D., 1960. Magnetic anisotropy in igneous rocks. J. Geophys. Res., 65: 2479-2442.
Taira, A., and Niitsuma, N., 1986. Turbidite sedimentation in the Nankal trough as interpreted from magnetic fabric, grain size and detrital modal analysis. In Kagami, H., Karig, D. E., et al., Init. Repts. $D S D P, 87$ : Washington (U.S. Govt. Printing Office), 611-632.

Westbrook, G. K., Mascle, A., and Biju-Duval, B., 1984. Geophysics and structure of the Lesser Antilles Forearc. In Buju-Duval, B., and Moore, J. C. et al., Init. Repts. DSDP, 78A: Washington (U.S. Govt. Printing Office), 23-38.

Date of initial receipt: 4 January 1988

Date of acceptance: 16 December 1988

Ms 110B-156

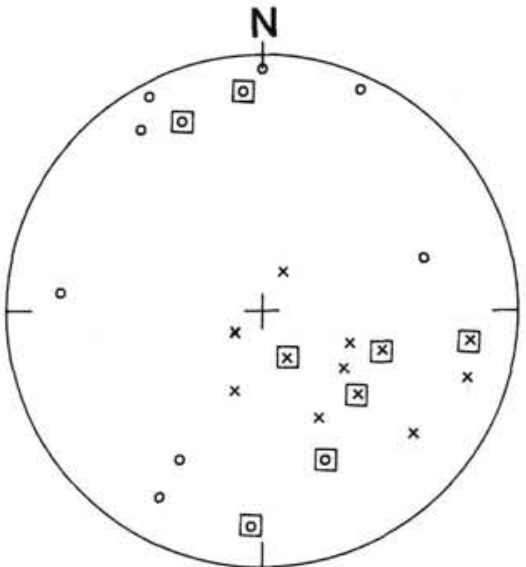

A)

$674 A-11 X, 12 X, 13 X, 15 X, 16 X$

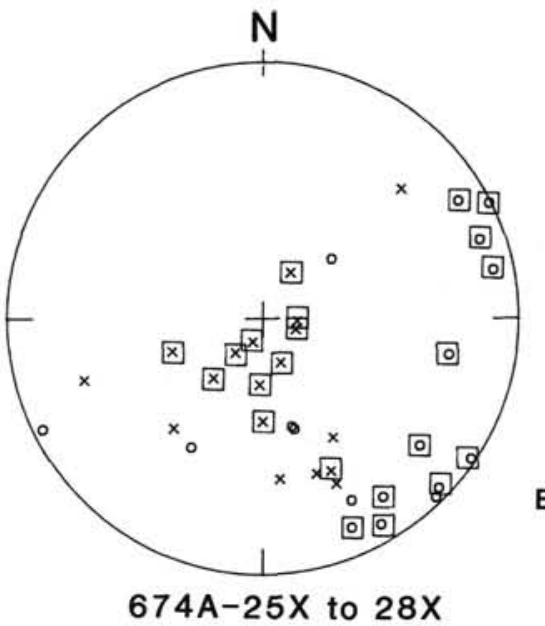

Figure 15. AMS data for samples from Hole 674A, in the intervals in which sub-horizontal scaly fabric is present, oriented using the natural remanent magnetisation direction (see Fig. 5 for key). 


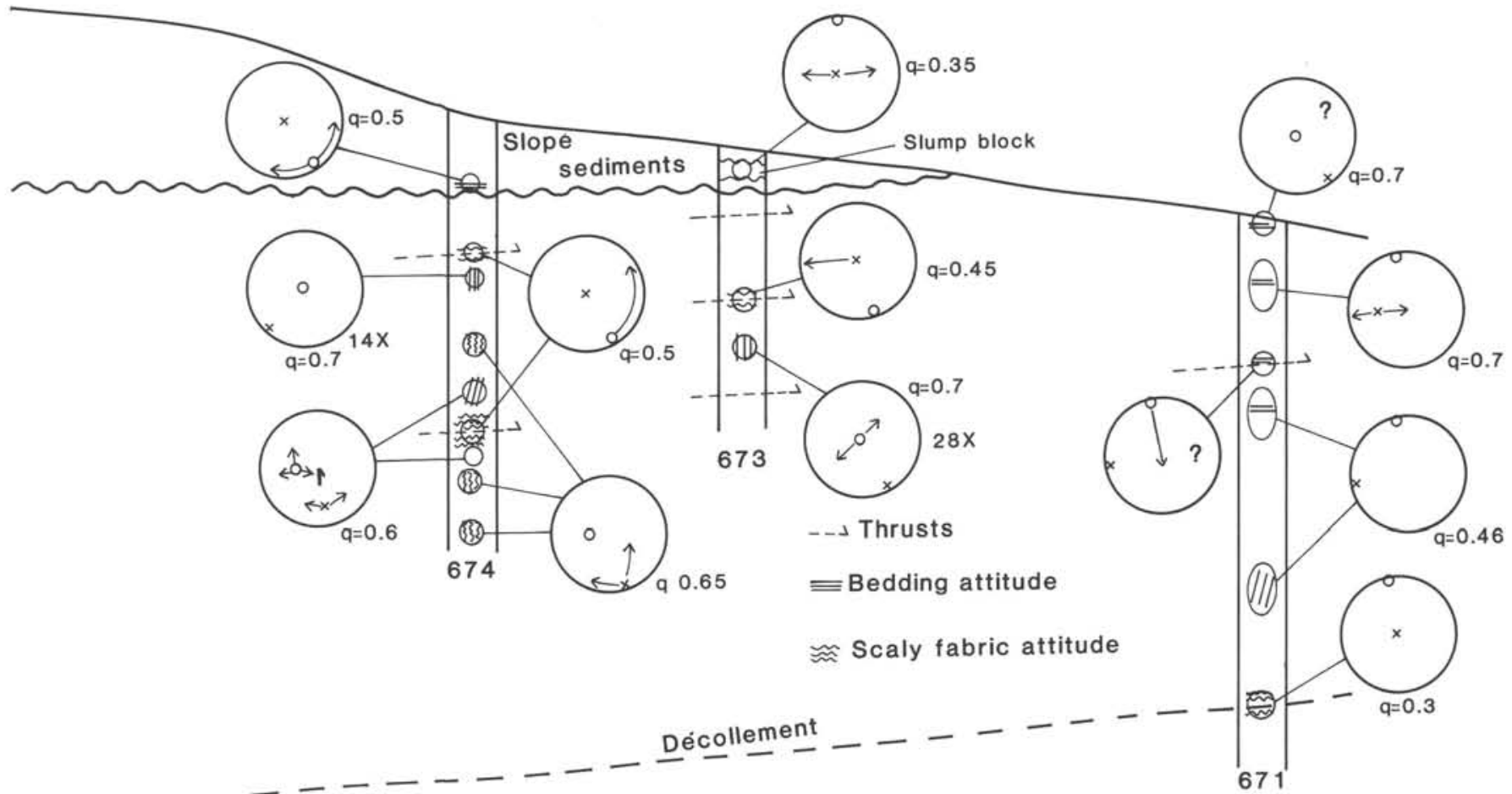

Figure 16. Schematic diagram summarizing the style of AMS encountered in the Barbados accretionary prism and its relationship to bedding, thrusts, and scaly fabric features. $K_{\max }$ and $K_{\min }$ axes are drawn on stereonets, with distribution of axes indicated with arrows, and typical $q$ values. Circles $K_{\max }$, crosses $K_{\min }$, are on stereographic projections. Not to scale. 


\section{APPENDIX}

AMS at samples from APC cores from Hole 673A, 673B, and 674A plotted relative to North and the core fiducial. The stereographic projections indicating $\mathrm{N}$ have samples oriented to North using individual sample data; that projection with no mark is plotted relative to the core liner fiducial. Thick arrows indicate the mean core geomagnetic north direction determined from the remanence data (Hounslow et al., this volume). Crosses $K_{\min }$, circles $K_{\max }$; upper hemisphere equal-area projection.
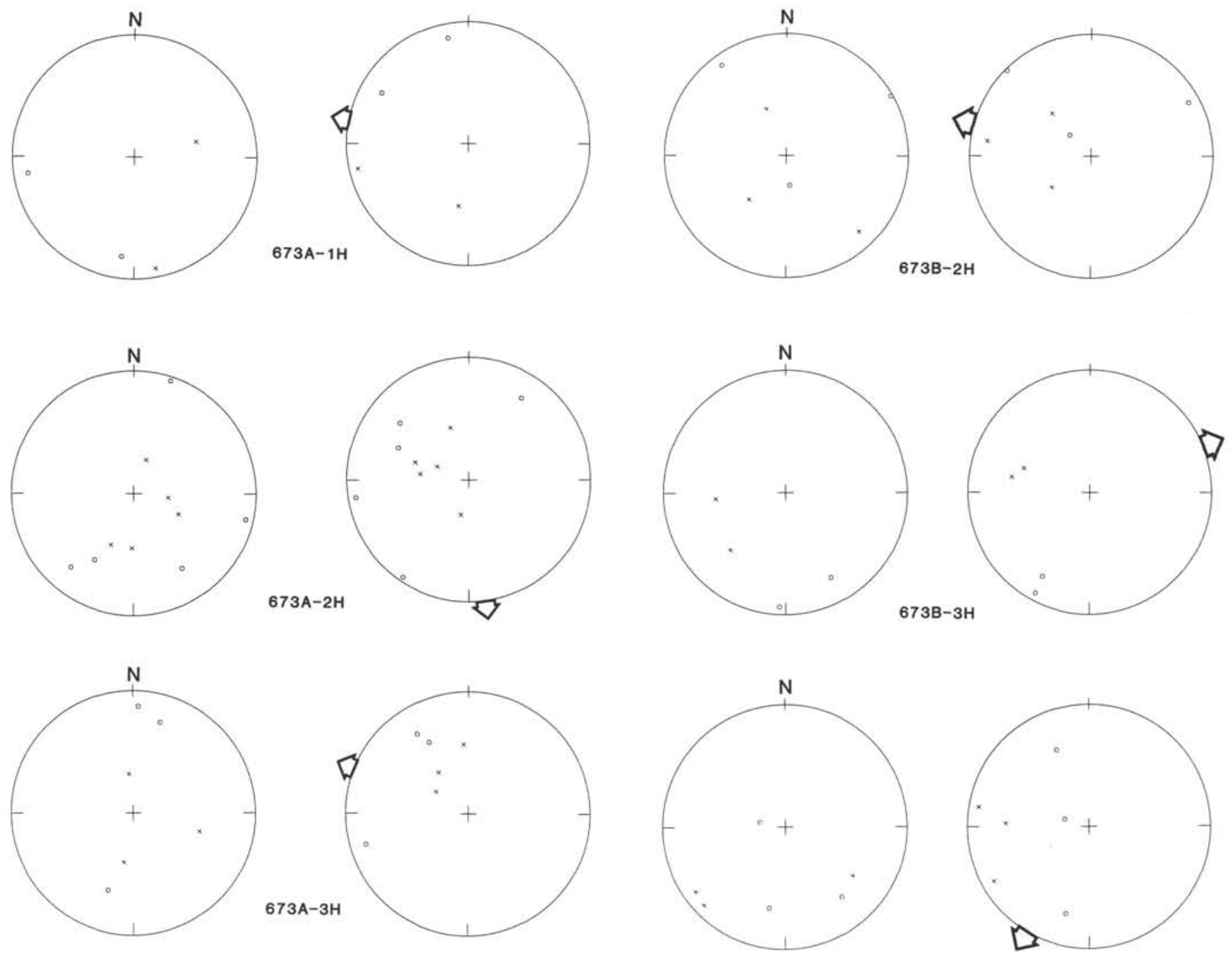

$673 \mathrm{~B}-4 \mathrm{H}$ 
GRAIN FABRIC IN DEFORMED SEDIMENTS
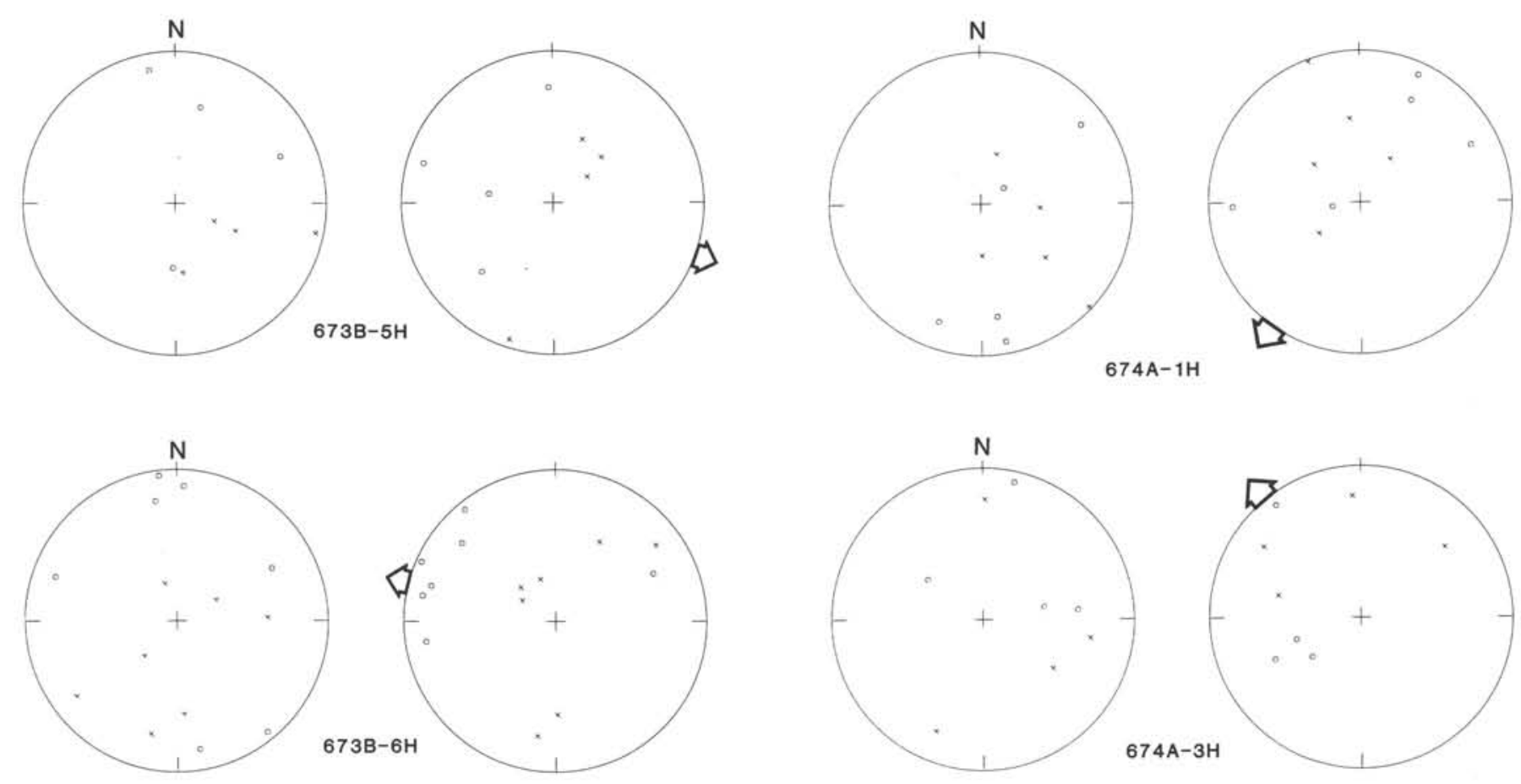

275 